\title{
Chinese characters: Semantic and phonetic regularity norms for China, Singapore, and Taiwan
}

\author{
SUSAN J. RICKARD LIOW, SIOK KENG TNG, and CHER LENG LEE \\ National University of Singapore, Singapore
}

\begin{abstract}
Cognitive models of language processing in English are founded on norms for word properties, but their universality is now being explored across different writing scripts and subject groups. Although Chinese characters are popular for this comparative work, their salient properties remain ill defined or poorly controlled. We describe how norms for semantic and phonetic regularity in Mandarin can be calibrated on a regional basis. The rating data that we present from China, Singapore, and Taiwan also illustrate why the diversity of both oral and written forms of Chinese should be considered in future empirical work.
\end{abstract}

Word properties are known to affect cognitive processing in English and other alphabetic scripts. Norms for these properties have been published cumulatively: word frequency (Carroll, Davies, \& Richman, 1971; Kučera \& Francis, 1967); concreteness, imagery, and meaningfulness (Paivio, Yuille, \& Madigan, 1968); word familiarity and pleasantness (Toglia \& Battig, 1978); age of acquisition (Gilhooly \& Logie, 1980); associative difficulty (Brown \& Ure, 1969); synonymity (Wilding \& Mohindra, 1981); and spelling-sound regularity (Berndt, Reggia, \& Mitchum, 1987; Venezky, 1970). Depending on the experimental design, other linguistic properties - such as the number of letters, number of phonemes, stress pattern, homophony, and so forth - might need to be controlled. For many cognitive tasks (e.g., perceptual recognition, naming, and lexical decision), multiple sources of information from different word properties affect processing. At the word level, these include the interaction of frequency and spelling regularity (Seidenberg, Waters, Barnes, \& Tanenhaus, 1984) and the conjoint influence of orthographic structure, spelling-to-speech correspondences, and word frequency (Massarro \& Cohen, 1994). At the word family level, neighborhood density (Andrews, $1989,1992)$ and word consistency (Glushko, 1979) have both been shown to have effects.

The importance of manipulating and controlling word properties with precision has led to the development of computerized compilations-for example, the U.K. Medical Research Council's psycholinguistic database for En-

This work was funded by the National University of Singapore (RP391/0067) and the Shaw Foundation. We are grateful to Hua Shu (China), S. Y. Tiang (Taiwan), Ming Lee Yong, Leh Woon Mok, Joy Ping P'ing, and Olivia Wee May Ling (Singapore) for their help with data collection and to Max Coltheart, Dan-ling Peng, Arthur Jacobs, Catherine McBride-Chang, Xiang Dong Jia, and two anonymous reviewers for their insightful comments on earlier versions. Correspondence concerning this article should be addressed to S. J. Rickard Liow, Department of Social Work and Psychology, National University of Singapore, Singapore S 119260 (e-mail: swksusan@nus.edu.sg). glish (Coltheart, 1981) and the Max-Planck Institute's (1995) CELEX Lexical Database for Dutch, English, and German. Despite Wu and Liu's (1988) preliminary work on Mandarin, this precision is not a standard practice for research on Chinese language processing. The availability and use of norms for empirical work on Chinese characters is very limited. Most experimenters control (or try to control) frequency and/or age of acquisition (H. C. Chen \& Leung, 1989; Woo \& Hoosain, 1984), and some have taken account of the number of strokes ${ }^{1}$ per character (Leong, Cheng, \& Mulcahy, 1987; Seidenberg, 1985), but the salience of other properties, including character regularity, has yet to be explored.

In English, word regularity (explained below) is known to have potent effects in a number of paradigms and for several different subject groups: skilled adult readers (Andrews, 1989, 1992; Kay \& Marcel, 1981; Parkin, 1982, 1984), young readers (Laxon, Masterson, \& Coltheart, 1991), and surface dyslexics (Coltheart, 1982; Coltheart, Masterson, Byng, Prior, \& Riddoch, 1983). The nature of the Chinese writing script, particularly the relationship between orthography and phonology, precludes drawing a simple parallel for characters. This begs the question of whether the cognitive models of reading, which have been developed for alphabetic scripts, could ever be adapted to fit nonalphabetic scripts (but see Hung \& Tzeng, 1981; Seidenberg, 1985; Yin \& Butterworth, 1992).

In what follows, we summarize the features relevant to this study of character regularity in Mandarin, but there are many other properties of Chinese languages that could influence performance on cognitive tasks. These include visual complexity, visual confusability, semantic relatedness, and syntagmatic relatedness in character groupings. The reason for our focus is that illustrating the satisfactory calibration of regularity will enable two elements of standard reading models to be investigated more systematically in Chinese. These are the nature of any (analogical) lexical-semantic processing and the plausibility of (assembled) nonlexical phonological processing. The universality of current dual (or multiple) route theories (e.g., 
Coltheart, Curtis, Atkins, \& Haller, 1993) depends primarily on these.

\section{THE CHINESE SCRIPT}

\section{Radicals}

Estimates vary, but at least $80 \%$ of Chinese graphemes are compound characters (Wang, 1973). They comprise a semantic radical (SR), which is sometimes called a signific, and a phonetic radical (PR). For example, in the compound character 清, which means clear or pure, the SR is written $\bar{i}$ and is associated with water, and the PR is written 青. As a simple character in Mandarin, this PR would be pronounced exactly like the compound itself. So, for 清, the SR does provide some information about the meaning, and the PR provides very accurate information about the phonology. However, not all radicals are as useful as these two, and it is the regularity of compound characters and their constituent radicals with which we are concerned in this paper.

Like 清, most compound characters are of the SR-PR type, such that the radical on the left (supposedly) provides information about the meaning of a character, and the radical on the right (supposedly) provides information about the phonology. However, the simplification of characters in China during the cultural revolution reduced the iconic nature of some so-called pictographs (e.g., 閉, meaning "shut, obstruct," simplified to 闭), and additional changes to the script continue to be made in order to accommodate new concepts. To keep pace with social, political, and technological developments, new compound characters are created using the rebus principle. This involves borrowing similar sounding (but semantically unrelated) syllables to act as PRs; the resulting homophones are then disambiguated by adding an SR. Hence, most new characters are compounds, which have a syllabic, as opposed to a logographic, structure.

So, for some time, character development has been based on speech, chiefly the phonology of Mandarin (DeFrancis, 1989). If the derivation of many present day characters is more phonetic than semantic, the popular view of characters as pictographs with rote-learned, unpredictable phonology is no longer tenable. The extent to which experimental subjects can (or do) make use of prelexical phonology remains debatable (see Perfetti \& Zhang, 1991, 1995). Script type and teaching methods probably account for some strategic variation, but so might the considerable differences in the phonology of spoken forms of Chinese.

\section{Phonology}

For syllabic (atonal) scripts, such as Japanese hiragana and katakana, the relationship between the grapheme and its phonology is regular. This is not so for Chinese: The phonology of a character comprises the phonemes of the syllable plus the tone in which the rime of that syllable is articulated. It is well known that spoken forms of different Chinese languages are not mutually intelligible, but the importance of tone differences is often overlooked (but see Taft \& Chen, 1992). The learner of a second Chinese language (L2)-say, Cantonese, when the first language (L1) is Mandarin - must cope with a new set of tones, as well as a different set of phonemes for most written characters. Given the very large number of homophones, tone phonology is the major obstacle for L2 learners of any Chinese language, because, without the correct tone, the syllable's meaning is changed completely.

\section{Homophones}

In English, heterographic homophones are sets of words with the same phonemes (same onset, same rime) but with different graphemic orders or elements-for example, wear and ware, but also rain and reign. In Chinese, homophony is more common, and several distinct written forms (e.g., 探, 炭, 叹, with three different meanings) can have identical phonology - in this case $\tan (4)$. The widespread homophony in Chinese has often been exploited in priming paradigms, but there is little consensus about the role of tone. A priori, we would expect a tone difference between characters with the same syllable phonology to render them nonhomophonic for the skilled speaker-hearer. The idea that homophony is (probably) tone sensitive has been neglected in some experiments (e.g., Fang, Horng, \& Tzeng, 1986) and compromised in others (e.g., Perfetti \& Zhang, 1991, 1995). Full appendices of stimuli are not always provided (e.g., Hue, 1992), but when they are, the heterogeneity of these stimuli is often evident.

\section{Simplified Versus Complex Characters}

Irrespective of the spoken form, the script for experimental purposes can be written in complex characters or, more commonly, in simplified characters. Leong et al. (1987) suggest that the likelihood of a confound is increased when differences between the original complex characters (still used in Hong Kong and Taiwan) and the simplified characters (used widely in China since the cultural revolution and, subsequently, in Singapore) are not observed. Theoretically, this is because the process of simplification might affect the orthography-phonology relationship of a compound character, as well as its visual representation, in terms of number and type of strokes. In practice, the effects of simplification have yet to be tested empirically, and this is one of the questions we begin to address by comparing subjects from different Chinese script backgrounds.

Given that characters have evolved over the last 2,000 years, it is not surprising that the orthography- phonology and orthography-semantics relationships are not regular within or between different Chinese languages or Chinese-speaking populations. As with alphabetic scripts, there are degrees of regularity among the characters and the languages. In English, regularity refers to the orthography-phonology relationship-specifically, the predictability of the word's phonology from its constituent graphemes (Venezky, 1970). For example, in their study of developmental dyslexia, Castles and Coltheart 
(1993) classified check and tail as regular but blood and colonel as irregular. In Chinese, character regularity comprises two separable aspects: semantic regularity and phonetic regularity.

\section{Semantic Regularity}

This refers to the orthography-semantics relationship between the compound character and its semantic radicalthat is, the predictability of the character's meaning from its constituent SR. Although the SR sometimes provides useful information about the compound character, the meanings are usually more symbolic and general, rather than pictographic and specific. According to Hsu (1976), the SR for the concept female (女) evolved from a kneeling human figure and, over time, was combined with a series of phonetic radicals to convey meanings as diverse as good (好), wicked (奸), milk (奶), and visit prostitutes (嫖).

The SR for some of the new characters has been added to disambiguate homophones, but it may provide little or no information about meaning. Over 625 compound characters contain the tree/wood radical ( $\$)$, but for many of them the SR is not very useful-for example, quarrel (架) and village (村) (examples from Paradis, 1989). We sampled characters from each of 36 SR sets in order to test subjects' sensitivity to different levels of semantic regularity. The sets were roughly equated for familiarity using age-of-acquisition (AoA) norms. In Singapore and elsewhere, it is common practice to teach characters in a prescribed order throughout primary and secondary school years. This means that AoA is likely to be a more reliable indicator of subjects' familiarity with a particular compound than are the objective frequency counts that have often been used in most empirical work.

\section{Phonetic Regularity}

This second kind of regularity for characters refers to the orthography-phonology relationship between the compound character and its PR - that is, the predictability of a character's phonology from its constituent PR. In some sense, character phonetic regularity is similar to alphabetic grapheme-phoneme mappings, but differences in phonology, especially tone assignment, mean that a close parallel cannot be drawn. Tones are an integral part of spoken Chinese, and in Hanyu Pinyin, a Romanized alphabetic form of Mandarin, they are marked with diacritics or the numbers (1) to (4). Although tone is not marked in the more customary logographic script, the PRs often provide information about the tone phonology of the compound character as well as about its syllable phonology. As with SRs, the accuracy of this information varies from character to character, and there are several ways of categorizing the relationship between the phonology of the PR and that of a compound character. According to DeFrancis (1989), one plausible fourfold categorization of phonetic regularity is: same phonemes/same tone (SPST), for example, 供 gong(4) and 共 gong(4); same phonemes/ different tone (SPDT), for example, 唱 chang(4) and 昌 chang(1); similar phonemes (SMLP), for example, 迨 dai(4) and 台 tai(2); different phonemes (DFTP), for example, 阪 gui(1) and 反 fan(3). ${ }^{2}$ We sampled high-frequency characters from each of these categories in order to test subjects' sensitivity to four different levels of phonetic regularity.

We focused on semantic and phonetic regularity, because these properties alone will enable two elements of dual (or multiple) route reading models to be investigated systematically: the nature of any (analogical) lexical- semantic processing and the plausibility of (assembled) nonlexical phonological processing. We wanted to question the plausibility of such models for nonalphabetic scripts, and look for discrepancies between groups of Mandarin users from different backgrounds. We reasoned that, if script simplification and/or cultural and pedagogical differences do affect strategies, regularity norms would need to be collected on a regional basis.

Character regularity was operationalized, using skilled readers' ratings of the usefulness of the $S R$ and the usefulness of the $P R$ for a set of compound characters, sampled from different AoA levels. Ratings were collected in China, Singapore, and Taiwan in order to compare perceptions of the simplified and complex forms of the script.

\section{METHOD}

The 7-point rating scales we developed to collect the regularity norms assumed that subjects would use (a version of) Mandarin phonology, but script type was varied according to region: The simplified form was used in China and Singapore, but the complex form was used for Taiwanese subjects. Two lists of compound characters were selected from Loo (1989): one for ratings of the usefulness of the SR and one for ratings of the usefulness of the PR. In place of number of strokes or frequency, we sampled characters according to AoA. Primary 1 to 6, CL2, and CL1 (respectively Chinese at second language and first language levels in secondary school).

\section{Semantic Radical List}

A list of 256 compound characters was compiled. Thirty-six of the most common SRs (out of a possible total of 214) were selected and combined with a set of PRs so that each of the eight AoA levels was represented for each SR, as far as possible. For half the SRs $(n=18)$, it was possible to cross AoA completely ( 152 characters), but for the other half, there were some missing AoA cells (104 characters). ${ }^{3}$

\section{Phonetic Radical List}

A list of 96 compound characters was compiled, using a sample of PRs paired with a variety of SRs. The list comprised 24 characters from each of DeFrancis's (1989) four categories of the orthographyphonology relationship between the PR and the compound. As far as possible, the four categories were matched for AoA levels, using the Singapore Ministry of Education's (1982) handbook. ${ }^{4}$

\section{Design of Rating Scale}

The rating scales for the $\mathrm{SRs}$ and $\mathrm{PRs}$ were similar. A 7-point rating scale was constructed, where $1=$ not at all useful and $7=$ very useful. Instructions to subjects were modeled on Toglia and Battig's 
(1978) collection of the Colorado norms (see below). Order of presentation was counterbalanced, using a Latin-square across pages, pseudorandomized within pages, and order of pages was counterbalanced across subjects.

\section{Subjects}

It is difficult, if not impossible, to match subjects from different cultural and educational backgrounds, even when their language usage overlaps. In Singapore, English is the main medium for education, and most ethnic Chinese children learn Mandarin as a second language (or mother tongue) throughout school. On average, the Mandarin proficiency is higher in China and Taiwan, so the AoA norms used for character sampling must be considered as conservative for these groups. The Singapore subjects $(n=198)$ were first- and second-year undergraduate students, between 19 and 25 years of age, from the Chinese Studies Department at the National University of Singapore. The students' teaching sessions and written work in this department are in Mandarin at a standard beyond "A" level. The subjects ( $n=75)$ from China (Beijing) and the subjects $(n=51)$ from Taiwan were senior high school students (i.e., about 3 years younger than those from Singapore). We reasoned that this age difference would act as an adjustment for proficiency in Mandarin.

\section{Procedure}

In Singapore, data for the SRs and the PRs were collected separately from the first $(n=131)$ and second $(n=67)$ year cohorts, respectively, but the same groups of subjects rated both sets of characters in China and Taiwan, in counterbalanced order. Written instructions to subjects were as follows: Characters differ in how use$f u l$ their phonetic (or semantic) radicals are for the pronunciation (or comprehension) of the character as a whole. Some radicals are very useful but others are not at all useful. Your task is to judge the usefulness of the phonetic (or semantic) radical for the pronunciation (or comprehension) of a list of characters using a 7-point rating scale where $\mathrm{I}=$ not at all useful and $7=$ very useful. Indicate your rating by putting a circle around the number that fits your judgment of usefulness.

All the subjects were debriefed and reassured that their ratings were made anonymously and were not part of an assessment procedure.

\section{RESULTS AND DISCUSSION}

The means and standard deviations for each rated character were computed separately for China, Taiwan, and Singapore. These are listed, together with statistical test results for each pair of regions, in the appendices. For semantic regularity (see Appendix A), each of the $256 \mathrm{com}$ pound characters is numbered according to its radical grouping (SR\#) and its AoA level ( 1 to 8$)$. For phonetic regularity (see Appendix B), each of the compound characters is numbered consecutively (\#1 to \#96) but listed within one of the four orthography-phonology categories: SPST, SPDT, SMLP, and DFTP. Whenever the complex character, which was used throughout for the Taiwan scale, has been simplified in the Singapore and China scales, both versions are shown. We have provided a rough guide to the meaning of the 256 characters rated for semantic regularity and a Hanyu Pinyin transcription with tone for the 96 characters rated for phonetic regularity, so that nonMandarin speakers can readily understand the analyses.

The relationship between the ratings and differential cognitive processing strategies awaits empirical investi- gation, using standard paradigms such as priming, translation, naming, and verification. However, we want to argue that the results, which are summarized below, reflect a high degree of heterogeneity within and between the SR sets and the PR categories, especially across the three subject groups. This suggests that semantic and phonetic regularity should command more attention and precision as psycholinguistic variables in future work on Chinese characters.

\section{Semantic Regularity}

The Chinese script is morphosyllabic and, thus, likely to be more amenable to lexical--semantic processing strategies than are alphabetic scripts. Despite this contrast, semantic regularity has received little attention in the crosslinguistic research on reading models. In Appendix A, the mean ratings for 36 common SRs depict an extensive range of perceived semantic regularity. Variation is evident both within SR sets and across different radicals. The highest and lowest mean ratings for radical sets were made by subjects from China (respectively, SR\#3.0 D, $M=6.07, S D=0.41$, meaning associated with mouth; and SR\#31.0 户, $M=2.40, S D=0.83$, meaning associated with corpse, image). The highest and lowest mean ratings for individual characters were also made by subjects from China within the same radical sets (respectively, SR\#3.1 唱, $M=6.56, S D=1.15$, meaning sing; and SR\#31.8 犀, $M=1.49, S D=1.30$, meaning rhinoceros). The relative size of the standard deviations for individual characters provides a rough gauge of agreement within the three subject groups, but we will consider radical sets and subject groups separately.

Semantic radical sets. The meanings we have listed for the individual compound characters are approximate in two ways. First, many compound characters are homographs, and, second, some concepts are not readily translated from Mandarin into English. Despite the fact that our guide is rough, it does dispel the myth that the script is pictographic at the radical or compound character level. Some SRs do seem more iconic than others, but their pictographic nature does not appear to influence semantic regularity ratings uniformly across compound characters, as might be expected. Two of the more pictographic SRs in our sample are SR\#3.0 and SR\#25.0. As noted earlier, SR\#3.0 $\square$ represents a mouth and received high ratings for semantic regularity, but there was some variation across compound characters and subject groups: For SR\#3.1 唱, meaning sing, mean ratings across regions range from 6.33 to 6.56 , but for SR\#3.8 呵, meaning breathe (out), scold (same SR), mean ratings range from 4.82 to 5.51 . Similarly, SR\#25.0 $\square$ represents an enclosure, and for SR\#25.7 囚, meaning imprison, mean ratings range from 5.77 to 6.63 ; yet, for SR\#25.1 国, meaning country, mean ratings are lower, ranging from 3.67 to 4.24. Although our sample of characters for some radicals also shows extremes of high regularity (e.g., SR\#1.0 f,

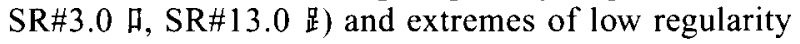
(e.g., SR\#16.0 王, SR\#22.0 $\rightarrow, S R \# 34.0$ ), ratings within 


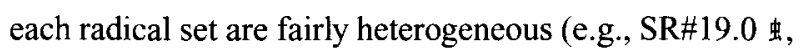
$\mathrm{SR} \# 21.0$ \#, SR\#24.0 (⿱⺌兀).

We obtained ratings on only 36 of the possible 214 groups, but most of these are among the most frequent by token count. It is clear that subjects from all three regions are sensitive to semantic regularity for these relatively high frequency compound characters and that such a variable could determine whether a lexical or nonlexical strategy is viable in reading. The heterogeneity we observed in the ratings suggests that semantic regularity is character specific and that it is not a simple measure of iconicity.

Subject groups. Certain SRs could become more salient in the course of reading skill development, either as a result of exposure to teaching methods and scripts that support analytic strategies or because of unspecified cultural aberrations in character usage. We will try to separate these influences in the ensuing discussion of statistical differences between the ratings for the three subject groups.

First and foremost, there is good evidence that the groups of subjects were using the rating scales in the same way. Over the sample of 256 compound characters, there was no significant difference between the ratings for China $(M=4.22, S D=0.77)$, Singapore $(M=4.15, S D=0.81)$, and Taiwan $[M=4.15, S D=1.18 ; F(2,254)=.14, p>$ $.05]$. There was some agreement about which semantic radicals are regular (i.e., provide clues to the compound character's meaning) and which are irregular, but oneway analyses of variance (ANOVAs, with Tukey $a$ ) showed that the number of statistically significant differences between the three subject groups is striking. These differences are evident both at the level of radical sets and at the level of individual characters.

As Appendix A shows, there were no significant differences between the three subject groups for 15 of the 36 radical sets $(41.7 \%)$. This agreement across groups covers a wide range of the 7-point scale, and it includes sets where the SR itself has been simplified (e.g., SR\#5.0, $S R \# 32.0$ ) and those where it has not (e.g., SR\#10.0, $S R \# 12.0$ ). There are more significant differences between China and Taiwan $(n=18)$ than between China and Singapore $(n=7)$ or Taiwan and Singapore $(n=$ 10 ), but there is no evidence of a consistent direction for these differences: China $>$ Taiwan for 10 sets and Taiwan $>$ China for 8 sets. However, within most radical sets, there are consistent patterns (e.g., SR\#4.0, SR\#11.0, SR\#13.0, $S R \# 26.0, S R \# 29.0$ ), but SR\#9.0, where the semantic radical has been simplified, shows a more mixed pattern.

At the level of the 256 rated characters, there were 267 differences spread across 150 different characters $(34.8 \%$ of the possible maximum of 768). We are obliged to acknowledge the contribution of Type I errors to this large proportion of differences, but it still seems clear that the three subject groups hold different perceptions of semantic regularity for many characters. We sampled mostly high-frequency compound characters, but, given that subjects from China and Singapore rated the same simplified versions, the large number of differences could reflect disparate literacy levels or different pedagogical strategies.
A priori, the use of analytical (nonlexical) strategies for radicals would be likely to depend on exposure to a sufficiently large sample of compound characters, unless radical meanings are explicitly taught. Analytic strategies are probably less widely used in Singapore than in either Taiwan or China, but evidence for an effect of pedagogical differences between the three regions is not very strong. Comparing China and Singapore across 256 characters, subjects from China give significantly higher ratings than subjects from Singapore for 30 characters $(11.7 \%)$ but significantly lower ratings for 17 characters $(6.6 \%)$, there being no significant difference in the mean ratings for the remaining 209 characters. There are more differences between China and Taiwan $(n=119)$ and between Singapore and Taiwan $(n=101)$, but these differences are not readily explained by character simplification. Of the 256 characters, 170 have not been simplified for use in China or Singapore, and yet a relatively large proportion received ratings that were significantly different in both directions: China higher than Taiwan for 41 characters $(24 \%)$, with Taiwan higher than China for 34 characters $(20 \%)$; Singapore higher than Taiwan for 35 characters $(20.1 \%)$, with Taiwan higher than Singapore for 29 characters $(17.1 \%)$. For those remaining 86 characters that have been simplified for use in China and Singapore, a similar pattern emerged: China was higher than Taiwan for 23 characters (26.7\%), with Taiwan higher than China for 18 characters $(20.9 \%)$; Singapore was higher than Taiwan for 18 characters $(20.9 \%)$, with Taiwan higher than Singapore for 16 characters $(18.6 \%)$.

It seems, then, that even if complex and simplified characters do facilitate qualitatively different strategies, the optimal (or standard) cognitive processing skills developed by subjects could be different for other reasons. In sum, the results for rated semantic regularity suggest that it would be prudent to base future empirical work on Chinese characters, such as semantic-priming experiments, on locally gathered subjective norms rather than on etymological or linguistic observations.

\section{Phonetic Regularity}

Unlike semantic regularity, phonetic regularity has been the subject of a number of experiments. We were concerned about the simple regular/irregular dichotomy employed in some previous work (e.g., Yin \& Butterworth, 1992), the heterogeneity of subject groups (e.g., Seidenberg, 1985), and the possibility of confounds (Perfetti \& Zhang, 1991, 1995). The data we present in Appendix $B$ support a more fine-grained classification with at least four categories of phonetic regularity, because tone differences between characters proved salient. Anomalies between the two types of script and the three subject groups are also examined.

Phonetic radical categories. To assess the salience of tone differences between the compound character and the PR, we compared two of DeFrancis's (1989) four categories. Combining data from the three subject groups, ratings for the SPST category $(M=6.47, S D=0.49)$ were significantly higher than those for the SPDT category 
$[M=5.30, S D=0.74 ; t(190)=30.63, p<.001$, twotailed]. This suggests that tonal phonology is salient and is perceived as being different from syllable phonology; see Rickard Liow and Poon (1998) for further discussion of the development of tone phonological awareness. Then, to assess the salience of syllable phonology differences between the compound character and the PR, we compared the relevant three categories pairwise in order. Again, combining data from the three subject groups, ratings for the SPST category were significantly higher than those for the SMLP category $[M=3.78, S D=0.97$; $t(190)=24.9, p<.001$, two-tailed]; and similarly, ratings for the SMLP category were significantly higher than those for the DFTP category $[M=2.13, S D=0.74$; $t(190)=29.90, p<.001$, two-tailed]. These results provide clear support for a hierarchical classification of phonetic regularity, with syllable and tone phonology differences as separable factors.

Subject groups. Again, there is good evidence that the three subject groups were using the rating scale in the same way. Over the sample of 96 compound characters, there was no significant difference between the ratings for China $(M=4.54, S D=0.52)$, Singapore $(M=4.34, S D=$ $0.49)$, and Taiwan $[M=4.39, S D=0.70 ; F(2,188)=$ $2.30, p>.05]$. There was some agreement about which PRs provide useful information about the compound character's phonology, but one-way ANOVAs (with Tukey $a$ at $p<.05$ ) showed that there were several statistically significant differences between the subject groups. These differences, which were evident both at the level of PR categories and at the level of individual characters, reflect regional differences in perceived phonetic regularity.

A mixed two-factor ANOVA showed a significant main effect of radical category $[F(3,564)=2,168.91$, $p<.001]$ and an interaction between radical category and subject group $[F(6,564)=9.15, p<.001]$, although there was no main effect of subject group. This suggests that the subject groups showed broad agreement about the concept of phonetic regularity but were differentially sensitive to the fourfold classification. One-way ANOVAs (with Tukey $a$ at $p<.05$ ) showed that, for three phonetic regularity categories but not SMLP, ${ }^{2}$ the ratings for subjects from China were significantly higher than those for subjects from Singapore, although both were asked to rate the same simplified script: SPST, China $(M=6.59$, $S D=0.45)$, Singapore $(M=6.36, S D=0.48)$; SPDT, China $(M=5.59, S D=0.59)$, Singapore $(M=5.26$, $S D=0.68)$; DFTP, China $(M=2.33, S D=0.74)$, Singapore $(M=1.90, S D=0.62)$. These differences are probably attributable to two factors. First, as with the SR sets, the subjects from China were more likely to have been taught analytic nonlexical strategies for reading Mandarin, and they would probably have been more familiar with the regular alphabetic Hanyu Pinyin transcriptions. Second, the subjects from Singapore were all Mandarin/ English bilingual biscriptals, but often at home they would have been exposed aurally to other Chinese languages, such as Hokkien and Cantonese, both of which have phonology and tones that differ from those in Mandarin.
For the SPDT category, the ratings for the subjects from China were also significantly higher (Tukey $a$ at $p<.05$ ) than those obtained from Taiwan subjects $(M=4.98$, $S D=0.86$ ), who rated the complex version. This suggests that the subjects from Taiwan and Singapore were more sensitive to tone change and that subjects from (Beijing) China perceived more phonetic similarity between the phonetic radical and the compound character.

Although the sample of characters rated for phonetic regularity is small, it seems clear that Mandarin-speaking subjects from different language backgrounds could be processing the phonology of characters in different ways. Moreover, the discrepancies we have reported are not easily attributed to script simplification, for at least three reasons. First, the subject groups from China and Singapore, both of whom rated the same simplified script, show some disagreement in both directions. Second, differences between the simplified and complex characters do not always result in differences in ratings between Taiwan and China or between Taiwan and Singapore. In all, 28 of the 96 compound characters $(28.6 \%)$ of the phonetic regularity list have different forms in the simplified script. Of these, 8 characters have different SRs, and 5 have different PRs, so they must be seen as different characters. For the remaining 15 characters, the PR itself has been simplified, and yet 10 of this subgroup do not show a significant difference across subjects. Perhaps the lack of an effect of simplification is not surprising: Simply reducing the number of strokes and visual complexity will not affect the regularity of the graphemephoneme relationship.

\section{SUMMARY}

There are many serviceable texts on different aspects of the Chinese language-for example, DeFrancis (1989), Hsu (1976), Li and Thompson (1981), Liu, Chuang, \& Wong (1975), Wang (1973) - but none in the mainstream psycholinguistic literature that define and calibrate the scripts' properties with the precision that empirical work usually demands. As with the alphabetic languages, the development of a comprehensive database for Chinese script(s), which includes data for semantic and phonetic regularity on a larger sample of compound characters, will take years to evolve. Meanwhile, without some norms, comparative accounts of skilled reading and reading acquisition will be less likely to make progress. We focused on character regularity because it will enable the universality of dual (or multiple) route models to be tested. The differences we have observed between SR sets, PR categories, and subject groups suggest that modifications to standard models will be necessary and that psycholinguistic norms should be collected on a regional basis.

\section{REFERENCES}

ANDREWS, S. (1989). Frequency and neighbourhood effects on lexical access: Activation or search? Journal of Experimental Psychology: Learning, Memory, \& Cognition, 15, 802-814.

Andrews, S. (1992). Frequency and neighbourhood effects on lexical 
access: Lexical similarity or orthographic redundancy? Journal of $E x$ perimental Psychology: Learning, Memory, \& Cognition, 18, 234-254

Berndt, R. S., RegGia, J. A., \& Mitchum, C. C. (1987). Empirically derived probabilities for grapheme-to-phoneme correspondences in English. Behavior Research Methods, Instruments, \& Computers, $19,1-9$

Brown, W. P., \& URE, D. M. J. (1969). Five rated characteristics of 650 word association stimuli. British Journal of Psychology, 60, 233-249.

Carroll, J. B., Davies, P., \& Richman, B. (1971). The American Heritage word frequency book. Boston: Houghton Mifflin.

Castles, A., \& ColthearT, M. (1993). Varieties of developmental dyslexia. Cognition, 47, 149-180.

Chen, H. C., \& LeUnG, Y. S. (1989). Patterns of lexical processing in a non-native language. Journal of Experimental Psychology: Learning, Memory, \& Cognition, 15, 316-325.

Chen, M. J., \& Yung, Y. F. (1989). Reading Chinese words: A holistic or piecemeal process? In A. F. Bennett \& K. M. McConkey (Eds.), Cognition in individual and social contexts (pp. 69-126). Amsterdam: North-Holland.

COLTHEART, M. (1981). The MRC psycholinguistic database. Quarterly Journal of Experimental Psychology, 33A, 497-505.

ColTHEART, M. (1982). The psycholinguistic analysis of acquired dyslexias: Some illustrations. Philosophical Transactions of the Royal Society of London: Series B, 298, 151-164.

Coltheart, M., Curtis, B., Atkins, P., \& Haller, M. (1993). Models of reading aloud: Dual route and parallel distributed approaches. Psychological Review, 100, 589-608.

Coltheart, M., Masterson, J., Byng, S., Prior, M., \& Riddoch, J. (1983). Surface dyslexia. Quarterly Journal of Experimental Psychologv, 35A, 469-495.

DeFrancis, J. (1989). Visible speech: The diverse oneness of writing systems. Honolulu: University of Hawaii Press.

FANG, S. P., HornG, R. Y., \& TZENG, O. (1986). Consistency effects in the Chinese character and pseudo-character naming tasks. In H. R. Kao \& R. Hoosain (Eds.), Linguistics, psychology and the Chinese language (pp. 11-21). Hong Kong: University of Hong Kong, Centre for Asian Studies.

Gilhooly, K. J., \& Logie, R. H. (1980). Age-of-acquisition, imagery, concreteness, familiarity, and ambiguity measures for 1,944 words. Behaviour Research Methods \& Instrumentation, 12, 395-427.

Glushko, R. J. (1979). The organisation and activation of orthographic knowledge in reading aloud. Journal of Experimental Psychology: Human Perception \& Performance, 5, 674-691.

Hsu, F. C. (1976). An analysis of the Chinese language: An etymological approach (Vol. 1). Pondicherry, India: Sri Aurobindo Ashram Trust

HuE, C. W. (1992). Recognition processes in character naming. In H. C. Chen \& O. J. L. Tzeng (Eds.), Language processing in Chinese (pp. 93107). Amsterdam: North-Holland.

Hung, D. L., \& TzENG, O. J. L. (1981). Orthographic variations and visual information processing. Psychological Bulletin, 90, 377-414.

KAY, J., \& MARCEL, A. (1981). One process, not two, in reading aloud: Lexical analogies do the work of non-lexical rules. Quarterly Journal of Experimental Psychology, 33A, 397-413.

KuČERA, H., \& FrANCIS, W. N. (1967). Computational analysis of presentday American English. Providence, RI: Brown University Press.

Laxon, V., Masterson, J., \& Coltheart, V. (1991). Some bodies are easier to read: The effect of consistency and regularity on children's reading. Quarterly Journal of Experimental Psychology, 43A, 793-824.

Leong, C. K., Cheng, P. W., \& Mulcahy, R. (1987). Automatic processing of morphemic orthography by mature readers. Language \& Speech, 30, 181-196.

Li, C. N., \& Thompson, S. A. (1981). Mandarin Chinese: A functional reference grammar. Berkeley: University of California Press.

Liv, I.-M., Chuang, C.-J., \& Wong, S.-J. (1975). Frequency counts of usually used Chinese words. Taipei: Lucky Books Company.

Loo, S. C. (1989). Frequency dictionary of Chinese characters -Words and phrases used in Singapore primary school textbooks. Singapore: National University of Singapore, Chinese Language and Research Centre.
Massarro, D. W., \& Cohen, M. M. (1994). Visual, orthographic, phonological, and lexical influences in reading. Journal of Experimental Psychology: Human Perception \& Performance, 20, $1107-1128$.

MINISTRY OF EDUCATION (1982). Chinese language syllabus for the new education system. Singapore: Educational Publications Bureau.

Paivio, A., Yuille, J. C., \& Madigan, S. A. (1968). Concreteness, imagery and meaningfulness values for 925 nouns. Journal of Experimental Psychology Monographs, 76 (1, Pt. 2).

Paradis, M. (1989). Linguistic parameters in the diagnosis of dyslexia in Japanese and Chinese. In P. G. Aaron \& R. M. Joshi (Eds.), Reading and writing disorders in different orthographic systems (pp. 231266). Dordrecht: Kluwer.

Parkin, A. J. (1982). Phonological recoding in lexical decision; Effects of spelling-to-sound regularity depend on how regularity is defined. Memory \& Cognition, 10, 43-53.

Parkin, A. J. (1984). Redefining the regularity effect. Memory \& Cognition, 12, 287-292.

Perfetti, C. A., \& Zhang, S. (1991). Phonological processes in reading Chinese characters. Journal of Experimental Psychology: Learning, Memory, \& Cognition, 17, 633-643.

Perfetti, C. A., \& Zhang, S. (1995). Very early phonological activation in Chinese reading. Journal of Experimental Psychology: Learning, Memory, \& Cognition, 21, 24-33.

Rickard Liow, S. J., \& Poon, K. K.-L. (1998). Phonological awareness in multilingual Chinese children. Applied Psycholinguistics, 19, 339-362.

SEIDENBERG, M. S. (1985). The time course of phonological code activation in two writing systems. Cognition, 19, 1-30.

Seidenberg, M. S., Waters, G. S., Barnes, M. A., \& Tanenhaus, M. K. (1984). When does irregular spelling or pronunciation influence word recognition? Journal of Verbal Learning \& Verbal Behaviour, 23, 383-404.

TAFT, M., \& CHEN, H. C. (1992). Judging homophony in Chinese: The influence of tones. In H. C. Chen \& O. J. L. Tzeng (Eds.), Language processing in Chinese (pp. 151-170). Amsterdam: North-Holland.

Toglia, M. P., \& Battig, W. F. (1978). Handbook of semantic word norms. New York: Erlbaum.

VENEZKY, R. L. (1970). The structure of English orthography. The Hague: Mouton.

WANG, S. Y. (1973, February). The Chinese language. Scientific American, 228, 50-63.

Wilding, J., \& MoHindra, N. (1981). Ratings of the degree of synonymity of 279 noun pairs. British Journal of Psychology, 72, 231-240.

Woo, E. Y. C., \& Hoosain, R. (1984). Visual and auditory functions of Chinese dyslexics. Psychologia, 27, 164-170.

Wu, J.-T., \& LIU, I.-M. (1988). A database system about the psychological features of Chinese characters and words. In I.-M. Liu, H.-C. Chen, \& M. J. Chen (Eds.), Cognitive aspects of the Chinese language (pp. 171-186). Hong Kong: Asian Research Service.

Yin, W., \& ButTERworTh, B. (1992). Deep and surface dyslexia in Chinese. In H. C. Chen \& O. J. L. Tzeng (Eds.), Language processing in Chinese (pp. 151-170). Amsterdam: North-Holland.

\section{NOTES}

1. M. J. Chen and Yung (1989) report that number of strokes is not important, and, anyway, it is unlikely that stroke count alone will suffice as a measure of visual complexity.

2. Permutations of onset, rime, and tone between the PR and the compound character are also possible (Dan-Ling Peng, personal communication). These would range from total homophony (same onset, same rime, same tone) to total nonhomophony (different onset, different rime, different tone). To our knowledge, there is no published work that uses this exhaustive eightfold system, but the heterogeneity in our SMLP category suggests that it merits investigation.

3. Some characters may have been rated for semantic regularity as if they were in combination with another compound, but this would be true for all subject groups.

4. We have assumed that where there is more than one pronunciation, subjects would have rated the homophone with the highest frequency. 
APPENDIX A

Semantic Regularity Ratings

Means and Standard Deviations (7-Point Scale) for Age-of-Acquisition (AoA) Levels With One-Way Analysis of Variance (Tukey $a$ ) Results

Between China (C), Singapore (S), and Taiwan (T) Subjects

\begin{tabular}{|c|c|c|c|c|c|c|c|c|c|c|c|c|c|}
\hline $\begin{array}{l}\text { SR\# } \\
\text { AoA } \\
1.0 \\
\end{array}$ & $\frac{s}{f}$ & $\mathrm{C}$ & $\begin{array}{l}\text { Hanyu } \\
\text { Pinyin }\end{array}$ & $\begin{array}{c}\text { Meaning in } \\
\text { English }\end{array}$ & \multicolumn{2}{|c|}{$\begin{array}{c}\text { China } \\
\text { Mean /SD }\end{array}$} & \multicolumn{2}{|c|}{$\begin{array}{l}\text { Singapore } \\
\text { Mean/SD }\end{array}$} & \multicolumn{2}{|c|}{$\begin{array}{c}\text { Taiwan } \\
\text { Mean/SD }\end{array}$} & $\begin{array}{l}\mathrm{C} / \mathrm{S} \\
.05\end{array}$ & $\begin{array}{l}\mathrm{C} / \mathrm{T} \\
.05\end{array}$ & $\begin{array}{l}\mathrm{S} / \mathrm{T} \\
.05\end{array}$ \\
\hline 1.1 & 抱 & & bao (4) & hold, embrace & 6.51 & 1.01 & 6.11 & 1.19 & 6.25 & 1.66 & $\overline{\mathrm{ns}}$ & $\mathrm{ns}$ & $\overline{n s}$ \\
\hline 1.2 & 打 & & da (3) & strike, knock & 5.75 & 1.99 & 5.89 & 1.69 & 5.82 & 1.80 & ns & ns & ns \\
\hline 1.3 & 扶 & & fu (2) & support & 6.20 & 1.34 & 6.35 & 1.19 & 5.44 & 1.95 & ns & $c>t$ & $s>t$ \\
\hline 1.4 & 拔 & & ba (2) & pull (up), select & 5.66 & 1.83 & 5.99 & 1.43 & 5.18 & 2.24 & ns & ns & $s>t$ \\
\hline 1.5 & 抽 & & chou (1) & take out & 5.31 & 1.99 & 5.38 & 1.73 & 4.51 & 2.36 & ns & ns & $s>t$ \\
\hline 1.6 & 抖 & & dou (3) & tremble, shiver & 5.17 & 2.11 & 5.22 & 1.86 & 5.02 & 2.28 & ns & ns & ns \\
\hline 1.7 & 措 & & cuo (2) & $\begin{array}{l}\text { arrange, } \\
\text { manage }\end{array}$ & 4.93 & 2.03 & 5.52 & 1.70 & 4.69 & 2.28 & ns & ns & $s>t$ \\
\hline 1.8 & 拈 & & $\operatorname{nian}(1)$ & pick up & 5.37 & 2.05 & 5.42 & 1.43 & 5.45 & 2.11 & $\mathrm{~ns}$ & ns & ns \\
\hline \multicolumn{5}{|c|}{ SR\#1 TOTALS } & 5.61 & 0.50 & 5.74 & 0.40 & 5.30 & 0.57 & ns & ns & ns \\
\hline
\end{tabular}

$2.0 \quad$ (meaning associated with tree/wood)

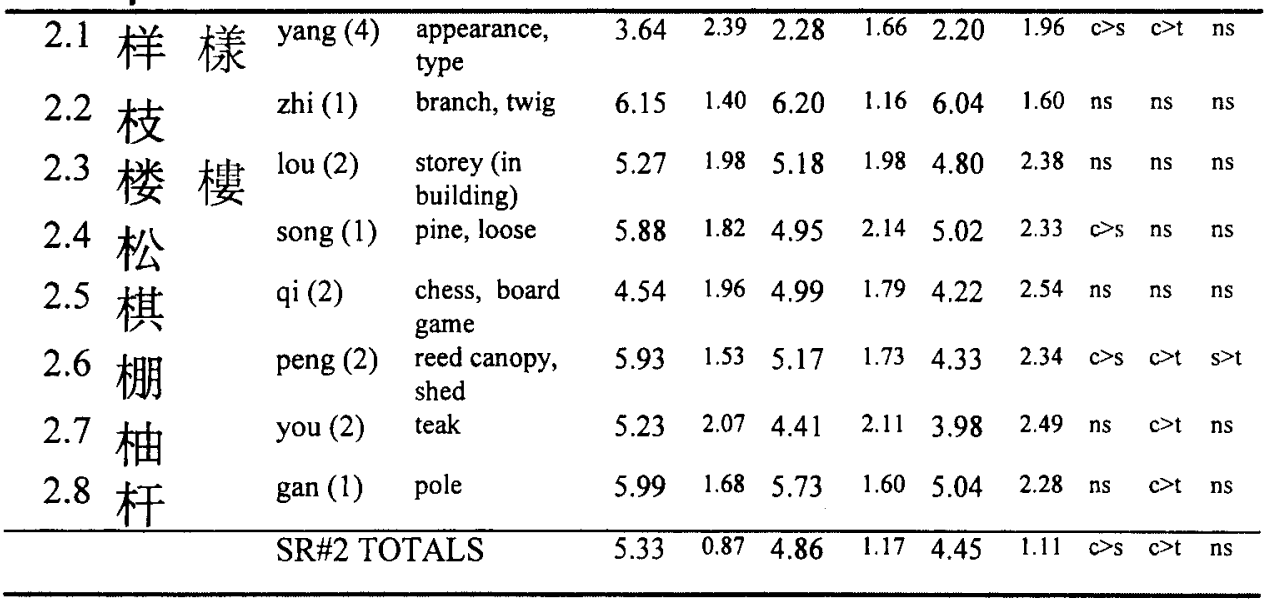

$3.0 \quad \| \quad$ (meaning associated with mouth)

\begin{tabular}{|c|c|c|c|c|c|c|c|c|c|c|c|}
\hline 3.1 唱 & chang (4) & sing & 6.56 & 1.15 & 6.39 & 6.39 & 6.33 & 1.23 & $\overline{n s}$ & ns & ns \\
\hline 3.2 吓 嚇 & xia (4) & $\begin{array}{l}\text { frighten, } \\
\text { intimidate }\end{array}$ & 5.49 & 2.00 & 4.29 & 2.22 & 5.14 & 2.15 & $c>s$ & ns & ns \\
\hline 3.3 吸 & xi (1) & inhale, suck up & 6.28 & 1.43 & 6.02 & 1.42 & 6.24 & 1.58 & ns & ns & $\mathrm{ns}$ \\
\hline 3.4 吩 & fen (1) & tell, instruct & 6.01 & 1.63 & 6.46 & 0.83 & 4.83 & 2.22 & ns & $c>t$ & $s>t$ \\
\hline 3.5 鸣 鳴 & $\operatorname{ming}(2)$ & $\begin{array}{l}\text { animal cry, } \\
\text { voice }\end{array}$ & 6.49 & 1.14 & 5.87 & 1.72 & 5.80 & 1.99 & $c>s$ & ns & ns \\
\hline 3.6 呻 & shen (1) & groan, moan & 6.29 & 1.41 & 6.20 & 1.31 & 5.10 & 2.28 & ns & $c>t$ & $s>t$ \\
\hline 3.7 哨 & shao (4) & warble, whistle & 5.95 & 1.69 & 6.45 & 0.82 & 5.14 & 2.08 & ns & $c>t$ & $s>t$ \\
\hline 3.8 呵 & he (1) & $\begin{array}{l}\text { breathe (out), } \\
\text { scold }\end{array}$ & 5.51 & 2.01 & 5.31 & 1.73 & 4.82 & 2.30 & ns & ns & ns \\
\hline & \multicolumn{2}{|c|}{ SR\#3 TOTALS } & 6.07 & 0.41 & 5.87 & 0.75 & 5.43 & 0.61 & ns & $c>t$ & $s>t$ \\
\hline
\end{tabular}




\section{APPENDIX A (Continued)}

\begin{tabular}{|c|c|c|c|c|c|c|c|c|c|c|c|c|c|}
\hline $\begin{array}{l}\text { SR\# } \\
\text { AoA }\end{array}$ & $\mathbf{S}$ & $\mathrm{C}$ & $\begin{array}{l}\text { Hanyu } \\
\text { Pinyin }\end{array}$ & $\begin{array}{c}\text { Meaning in } \\
\text { English }\end{array}$ & \multicolumn{2}{|c|}{$\begin{array}{c}\text { China } \\
\text { Mean } / \mathrm{SD}\end{array}$} & \multicolumn{2}{|c|}{$\begin{array}{l}\text { Singapore } \\
\text { Mean/SD }\end{array}$} & \multicolumn{2}{|c|}{$\begin{array}{c}\text { Taiwan } \\
\text { Mean/SD }\end{array}$} & $\begin{array}{l}\mathrm{C} / \mathrm{S} \\
.05\end{array}$ & $\begin{array}{l}\mathrm{C} / \mathrm{T} \\
.05\end{array}$ & $\begin{array}{l}\mathrm{S} / \mathrm{T} \\
.05\end{array}$ \\
\hline & & & & & & & & \multicolumn{6}{|c|}{ (meaning associated with water) } \\
\hline 4.1 & 河 & & he (2) & river & 6.49 & 1.31 & 6.42 & 0.91 & 5.57 & 2.18 & ns & $\mathrm{c}>\mathrm{t}$ & $s>t$ \\
\hline 4.2 & 洋 & & yang (2) & ocean, vast & 5.74 & 2.13 & 4.84 & 2.29 & 4.08 & 2.53 & $c>s$ & $c>t$ & $\mathrm{~ns}$ \\
\hline 4.3 & 油 & & you (2) & oil, grease & 5.92 & 1.61 & 5.27 & 1.63 & 5.18 & 2.16 & $\mathrm{c}>\mathrm{s}$ & ns & ns \\
\hline 4.4 & 消 & & xiao (1) & $\begin{array}{l}\text { disappear, } \\
\text { remove }\end{array}$ & 3.39 & 2.29 & 3.36 & 2.01 & 3.18 & 2.28 & ns & ns & $\mathrm{ns}$ \\
\hline 4.5 & 波 & & bo (1) & wave & 6.08 & 1.72 & 5.67 & 1.85 & 4.69 & 2.37 & ns & $c>t$ & $s>t$ \\
\hline 4.6 & 涂 & & tu (2) & smear, scribble & 4.31 & 2.05 & 3.60 & 2.23 & 2.12 & 2.10 & $\mathrm{~ns}$ & $c>t$ & $s>t$ \\
\hline 4.7 & 浑 & 湩 & hun (2) & muddy, foolish & 4.30 & 2.12 & 3.02 & 2.07 & 3.67 & 2.36 & $c>s$ & ns & ns \\
\hline \multirow[t]{2}{*}{4.8} & 滨 & 演 & $\operatorname{bin}(1)$ & bank, shove & 5.57 & 1.98 & 5.59 & 1.60 & 4.53 & 2.26 & ns & $c>t$ & $s>t$ \\
\hline & & \multicolumn{3}{|c|}{ SR\#4 TOTALS } & 5.23 & 1.09 & 4.72 & 1.25 & 4.13 & 1.12 & $\mathrm{c}>\mathrm{s}$ & $\mathrm{c}>\mathrm{t}$ & $s>t$ \\
\hline
\end{tabular}

$5.0 \quad i \quad$ (meaning associated with speech/word)

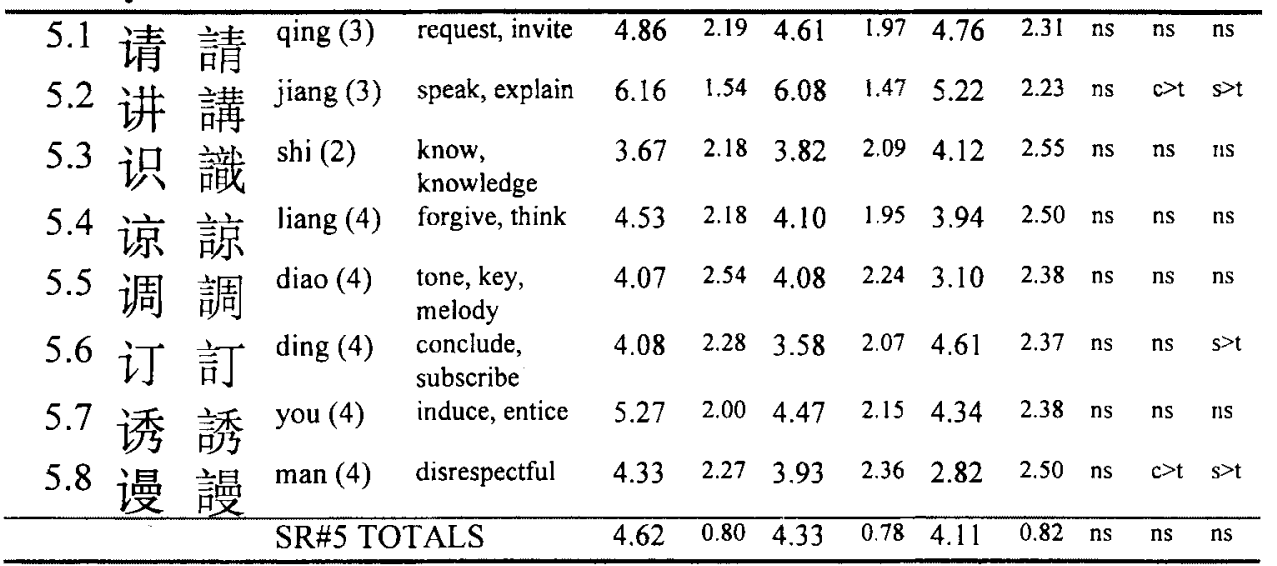

6.01 (meaning associated with person $/ \mathrm{man}$ )

\begin{tabular}{|c|c|c|c|c|c|c|c|c|c|c|c|c|c|}
\hline 6.1 & 扸 & & $\operatorname{ta}(\mathrm{I})$ & he, another & 4.79 & 2.35 & 5.46 & 2.06 & 4.43 & 2.56 & ns & ns & $s>t$ \\
\hline 6.2 & 保 & & bao (3) & $\begin{array}{l}\text { protect, } \\
\text { guarantee }\end{array}$ & 3.27 & 2.33 & 3.81 & 2.14 & 3.41 & 2.57 & ns & ns & ns \\
\hline 6.3 & 份 & & fen (4) & portion, share & 4.07 & 2.33 & 4.15 & 2.23 & 4.92 & 2.31 & ns & ns & ns \\
\hline 6.4 & 仙 & & xian (1) & immortal & 5.24 & 2.25 & 5.26 & 1.99 & 5.88 & 1.87 & ns & ns & ns \\
\hline 6.5 & 优 & 傮 & you (1) & excellent & 3.49 & 2.51 & 3.42 & 2.02 & 3.31 & 2.53 & ns & ns & ns \\
\hline 6.6 & 借 & & jie (4) & borrow/lend & 2.91 & 2.19 & 4.23 & 2.05 & 5.57 & 2.17 & $s>c$ & $\mathrm{t}>\mathrm{c}$ & $\mathrm{t}>\mathrm{s}$ \\
\hline 6.7 & 伦 & 倫 & $\operatorname{lun}(2)$ & logic, peer & 2.49 & 1.87 & 3.98 & 2.41 & 3.73 & 2.42 & $s>c$ & $p c$ & $\mathrm{~ns}$ \\
\hline 6.8 & 俭 & 剑 & kuai (4) & middleman & 3.12 & 2.23 & 3.47 & 2.26 & 2.55 & 2.18 & ns & ns & ns \\
\hline & & & \multicolumn{2}{|c|}{ SR\#6 TOTALS } & 3.67 & 0.95 & 4.22 & 0.76 & 4.22 & 1.17 & $s>c$ & ns & ns \\
\hline
\end{tabular}


APPENDIX A (Continued)

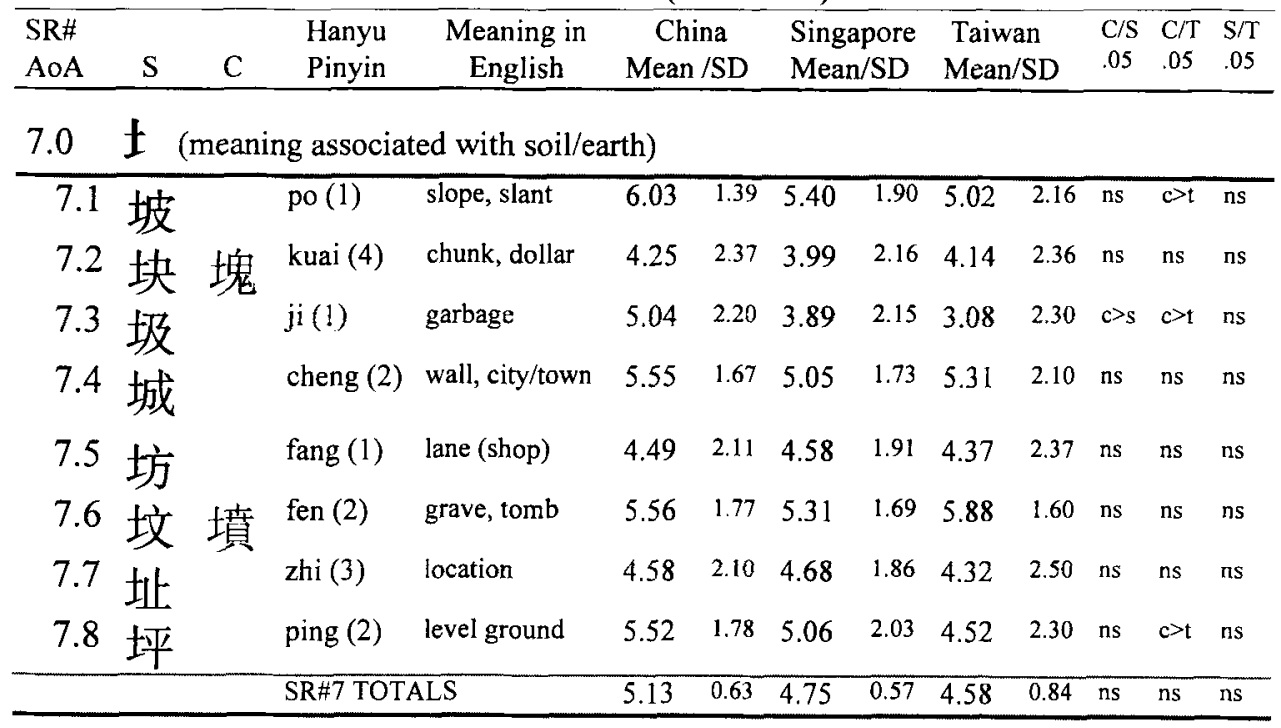

\begin{tabular}{|c|c|c|c|c|c|c|c|c|c|c|c|c|c|}
\hline & & & $\operatorname{lign}(2)$ & face & 518 & 106 & 175 & 226 & $50 ?$ & 236 & $n$ & nc & \\
\hline 8.1 & 脸 & 臉 & $\operatorname{lian}(3)$ & face & 5.48 & 1.96 & 4.75 & 2.26 & 5.02 & 2.36 & ns & ns & ns \\
\hline 8.2 & 肚 & & $\mathrm{du}(4)$ & stomach & 5.20 & 2.03 & 4.98 & 2.24 & 5.00 & 2.25 & ns & ns & ns \\
\hline 8.3 & 脑 & 腦 & nao (3) & brain & 5.23 & 1.89 & 4.82 & 2.14 & 4.92 & 2.19 & ns & ns & ns \\
\hline 8.4 & 肥 & & fei (2) & fat, fertile & 4.67 & 2.29 & 4.74 & 2.18 & 5.36 & 2.13 & ns & ns & ns \\
\hline 8.5 & 肝 & & $\operatorname{gan}(1)$ & liver & 5.62 & 1.77 & 4.91 & 2.06 & 5.45 & 2.08 & ns & ns & ns \\
\hline $8.6^{\mathrm{a}}$ & 肤 & 罆 & fu (1) & skin & 5.59 & 1.92 & 5.29 & 2.05 & 3.90 & 2.44 & ns & $c>t$ & $s>t$ \\
\hline 8.7 & 脆 & & cui (4) & fragile, crispy & 3.69 & 2.45 & 3.43 & 2.24 & 3.90 & 2.45 & $\mathrm{~ns}$ & ns & ns \\
\hline & & & \multicolumn{2}{|c|}{ SR\#8 TOTALS } & 5.07 & 0.69 & 4.70 & 0.59 & 4.79 & 0.64 & ns & ns & ns \\
\hline
\end{tabular}

\begin{tabular}{|c|c|c|c|c|c|c|c|c|c|c|c|c|c|}
\hline & & & & & & & & & & & & & \\
\hline 9.1 & $\underline{E}$ & 幻 & hong (2) & rea, bonus & 2.08 & $1 . \pi$ & 2.24 & 1.79 & 3.08 & 2.58 & ns & $\mathrm{p}>\mathrm{c}$ & $t>s$ \\
\hline 9.2 & 经 & 經 & jing (1) & warp, canon & 2.17 & 1.66 & 2.49 & 1.79 & 2.36 & 2.16 & ns & ns & ns \\
\hline 9.3 & 级 & 級 & $\mathrm{ji}(2)$ & grade, step & 2.15 & 1.76 & 2.23 & 1.54 & 2.43 & 2.07 & ns & ns & ns \\
\hline 9.4 & 丝 & 終 & zhong (1) & finish, death & 2.07 & 1.68 & 2.12 & 1.67 & 3.06 & 2.49 & ns & $t>c$ & $\mathrm{t}>\mathrm{s}$ \\
\hline 9.5 & 络 & 絡 & luo (4) & net, twine & 3.41 & 2.20 & 2.69 & 1.94 & 3.31 & 2.42 & ns & $\mathrm{ns}$ & ns \\
\hline 9.6 & 编 & 編 & bian (1) & plait, compose & 5.22 & 2.04 & 3.99 & 2.29 & 4.06 & 2.67 & $c>s$ & $c>t$ & ns \\
\hline 9.7 & 绘 & 繪 & hui (4) & paint, draw & 4.49 & 2.40 & 3.34 & 1.94 & 3.29 & 2.52 & $c>s$ & $c>t$ & ns \\
\hline 9.8 & 绽 & 綻 & zhan (4) & split, burst & 3.93 & 2.39 & 2.41 & 1.78 & 2.45 & 2.01 & $c>s$ & $c>t$ & ns \\
\hline \multicolumn{5}{|c|}{ SR\#9 TOTALS } & 3.19 & 1.25 & 2.69 & 0.65 & 3.01 & 0.58 & $\mathrm{c}>\mathrm{s}$ & ns & ns \\
\hline
\end{tabular}


APPENDIX A (Continued)

\begin{tabular}{|c|c|c|c|c|c|c|c|c|c|c|c|c|c|}
\hline $\begin{array}{l}\text { SR\# } \\
\text { AoA } \\
10.0\end{array}$ & $\begin{array}{l}s \\
\text { h }\end{array}$ & C & $\begin{array}{l}\text { Hanyu } \\
\text { Pinyin }\end{array}$ & $\begin{array}{c}\text { Meaning in } \\
\text { English }\end{array}$ & \multicolumn{2}{|c|}{$\begin{array}{c}\text { China } \\
\text { Mean /SD }\end{array}$} & \multicolumn{2}{|c|}{$\begin{array}{l}\text { Singapore } \\
\text { Mean/SD }\end{array}$} & \multicolumn{2}{|c|}{$\begin{array}{l}\text { Taiwan } \\
\text { Mean/SD } \\
\end{array}$} & $\begin{array}{l}\mathrm{C} / \mathrm{S} \\
.05\end{array}$ & $\begin{array}{l}\mathrm{C} / \mathrm{T} \\
.05 \\
\end{array}$ & $\begin{array}{l}\mathrm{S} / \mathrm{T} \\
.05 \\
\end{array}$ \\
\hline 10.1 & 好 & & hao (3) & good & 3.18 & 2.44 & 3.91 & 2.29 & 4.88 & 2.40 & ns & $\bar{p}>\mathrm{c}$ & $\mathrm{ns}$ \\
\hline 10.2 & 奶 & & nai (3) & milk, breast & 5.87 & 1.85 & 5.82 & 1.69 & 5.12 & 2.21 & ns & ns & ns \\
\hline 10.3 & 始 & & $\operatorname{shi}(3)$ & beginning & 1.92 & 1.56 & 1.65 & 1.24 & 2.62 & 2.21 & ns & $\mathrm{ns}$ & $\mathrm{t}>\mathrm{s}$ \\
\hline 10.4 & 姓 & & xing (4) & family name & 2.65 & 2.14 & 2.54 & 1.98 & 3.55 & 2.48 & ns & ns & $1>s$ \\
\hline 10.5 & 妇 & 婦 & fu (4) & $\begin{array}{l}\text { (married) } \\
\text { woman }\end{array}$ & 5.93 & 1.96 & 6.42 & 1.07 & 5.40 & 2.09 & ns & ns & $s>t$ \\
\hline 10.6 & 奸 & & jian (1) & $\begin{array}{l}\text { wicked, } \\
\text { adultery }\end{array}$ & 4.32 & 2.49 & 3.15 & 2.27 & 4.44 & 2.37 & $c>s$ & ns & $p s$ \\
\hline 10.7 & 始 & & fei (1) & $\begin{array}{l}\text { (imperial) } \\
\text { concubine }\end{array}$ & 5.54 & 2.06 & 6.20 & 1.27 & 4.92 & 2.21 & ns & ns & $s>t$ \\
\hline \multirow[t]{2}{*}{10.8} & 嫖 & & piao (2) & visit prostitutes & 5.59 & 2.02 & 5.78 & 1.60 & 4.61 & 2.44 & ns & $c t$ & $s>t$ \\
\hline & & & \multicolumn{2}{|c|}{ SR\#10 TOTALS } & 4.38 & 1.60 & 4.43 & 1.85 & 4.44 & 0.92 & ns & $\mathrm{ns}$ & ns \\
\hline
\end{tabular}

$11.0 \uparrow$ (meaning associated with heart)

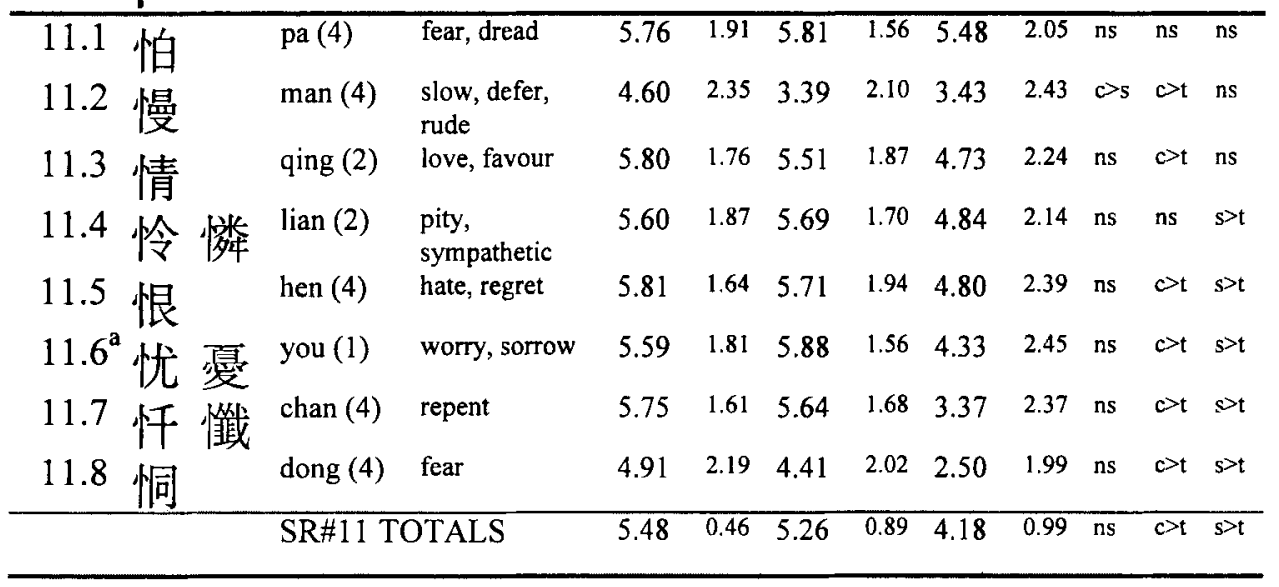

12.0 禾 (meaning associated with cereal crops)

\begin{tabular}{|c|c|c|c|c|c|c|c|c|c|c|c|}
\hline 12.1 和 & he (2) & gentle, peace & 2.57 & 1.97 & 2.50 & 2.00 & 3.90 & 2.39 & ns & $\mathrm{t}>\mathrm{c}$ & $\overrightarrow{\mathrm{t}>\mathrm{s}}$ \\
\hline 12.2 种 種 & zhong (4) & cultivate & 5.43 & 1.99 & 4.39 & 2.01 & 5.67 & 1.97 & $c>s$ & ns & $\mathfrak{t}>\mathbf{s}$ \\
\hline 12.3 利 & $\mathrm{li}(4)$ & sharp, benefit & 2.75 & 2.34 & 3.73 & 2.42 & 4.78 & 2.38 & $s>c$ & $\mathrm{t}>\mathrm{c}$ & $t>s$ \\
\hline 12.4 租 & $\mathrm{zu}(1)$ & rent, lease & 2.93 & 2.13 & 2.39 & 1.80 & 2.92 & 2.23 & ns & ns & ns \\
\hline 12.5 秒 & miao (3) & $\begin{array}{l}\text { second (in } \\
\text { time) }\end{array}$ & 2.44 & 1.99 & 2.99 & 2.14 & 3.36 & 2.62 & ns & ns & ns \\
\hline 12.6 稿 & gao (3) & stalk, draft & 3.56 & 2.27 & 2.99 & 2.09 & 2.41 & 2.20 & ns & $c>1$ & ns \\
\hline 12.7 稠 & chou (2) & thick, dense & 3.33 & 2.02 & 3.76 & 2.07 & 2.86 & 2.06 & $\mathrm{~s}>\mathrm{c}$ & $\mathrm{ns}$ & ns \\
\hline 12.8 穆 & $\mathrm{mu}(4)$ & solemn & 1.97 & 1.82 & 2.22 & 1.67 & 1.90 & 1.75 & ns & ns & ns \\
\hline & \multicolumn{2}{|c|}{ SR\#12 TOTALS } & 3.12 & 1.06 & 3.12 & 0.77 & 3.47 & 1.25 & ns & ns & ns \\
\hline
\end{tabular}


APPENDIX A (Continued)

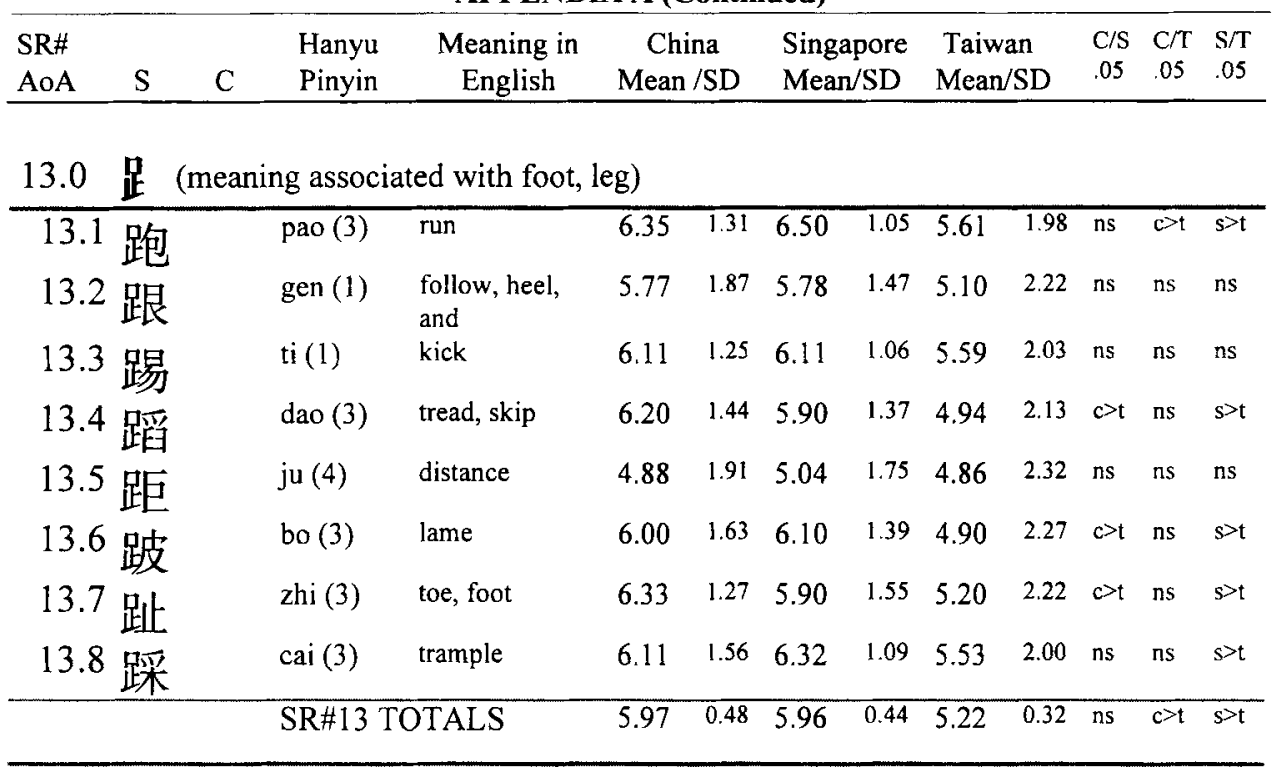

$14.0 \quad \beta$ (meaning associated with abundance)

\begin{tabular}{|c|c|c|c|c|c|c|c|c|c|c|c|}
\hline 14.1 阳 陽 & yang (2) & masculine, sun & 4.58 & 2.52 & 5.70 & 1.65 & 3.82 & 2.45 & $\mathrm{~s}>\mathrm{c}$ & $\overline{\mathrm{ns}}$ & $s>t$ \\
\hline 14.2 院 & yuan (4) & courtyard & 1.92 & 1.61 & 2.36 & 1.72 & 3.04 & 2.37 & ns & $p>c$ & ns \\
\hline 14.3 陈 陳 & chen (2) & display, state & 2.82 & 2.51 & 1.82 & 1.45 & 2.57 & 2.37 & $c>s$ & ns & ns \\
\hline 14.4 防 & fang (2) & prevent,defend & 2.43 & 1.88 & 2.17 & 1.56 & 3.70 & 2.48 & ns & $D c$ & $t>s$ \\
\hline 14.5 降 & jiang (4) & fall, lower & 1.76 & 1.59 & 1.91 & 1.28 & 2.71 & 2.36 & ns & $p c$ & $t_{s}$ \\
\hline 14.6 际 際 & ji (4) & $\begin{array}{l}\text { border, } \\
\text { occasion }\end{array}$ & 2.15 & 1.70 & 2.41 & 1.93 & 2.37 & 2.04 & ns & $\mathrm{ns}$ & ns \\
\hline 14.7 阻 & $\mathrm{zu}(3)$ & obstruct & 2.26 & 1.78 & 2.16 & 1.64 & 3.33 & 2.43 & ns & $t_{c}$ & $t>s$ \\
\hline 14.8 陨 隕 & yun (3) & fall (from sky) & 1.84 & 1.41 & 2.17 & 1.62 & 2.84 & 2.46 & ns & $t>c$ & ns \\
\hline & SR\#14 TC & DTALS & 2.47 & 0.92 & 2.59 & 1.27 & 3.05 & 0.53 & ns & $t>c$ & ns \\
\hline $15.0 \nmid$ (meani & ng associat & ed with animal & & & & & & & & & \\
\hline 15.1 猫 貓 & mao (1) & cat & 5.77 & 1.84 & 5.69 & 1.77 & 4.58 & 2.51 & ns & $c>t$ & $s>t$ \\
\hline 15.2 猜 & cai (1) & speculate & 2.68 & 2.12 & 2.16 & 1.60 & 2.98 & 2.47 & ns & ns & ns \\
\hline 15.3 狼 & lang (2) & wolf & 5.68 & 1.89 & 5.83 & 1.62 & 4.82 & 2.43 & ns & $c>t$ & $s>t$ \\
\hline 15.4 狡 & jiao (3) & cunning & 4.36 & 2.26 & 4.20 & 2.09 & 4.12 & 2.37 & ns & ns & $\mathrm{ns}$ \\
\hline 15.5 狂 & kuang (2) & crazy, violent & 4.35 & 2.44 & 4.38 & 2.16 & 5.54 & 2.01 & ns & $t>c$ & $\mathrm{t}>\mathrm{s}$ \\
\hline 15.6 狠 & hen (3) & ruthless & 4.09 & 2.42 & 4.54 & 2.14 & 4.06 & 2.40 & ns & ns & ns \\
\hline 15.7 犹 猶 & you (2) & just as, still & 2.43 & 1.86 & 2.52 & 1.92 & 2.37 & 2.14 & ns & ns & ns \\
\hline 15.8 狞 獶 & ning (2) & $\begin{array}{l}\text { ferocious, } \\
\text { hideous }\end{array}$ & 4.73 & 2.15 & 4.53 & 2.24 & 3.06 & 2.44 & ns & $c>t$ & $s>t$ \\
\hline & \multicolumn{2}{|c|}{ SR $\# 15$ TOTALS } & 4.26 & 1,22 & 4.23 & 1.32 & 3.94 & 1.07 & ns & ns & ns \\
\hline
\end{tabular}




\section{APPENDIX A (Continued)}

\begin{tabular}{llllccccccc}
\hline SR\# & & & Hanyu & Meaning in & China & Singapore & Taiwan & C/S & C/T & S/T \\
AoA & $\mathrm{S}$ & $\mathrm{C}$ & $\begin{array}{l}\text { Pinyin } \\
\text { English }\end{array}$ & Mean $/ \mathrm{SD}$ & Mean/SD & Mean/SD & .05 & .05 & .05 \\
\hline
\end{tabular}

16.0 王 (meaning associated with jade)

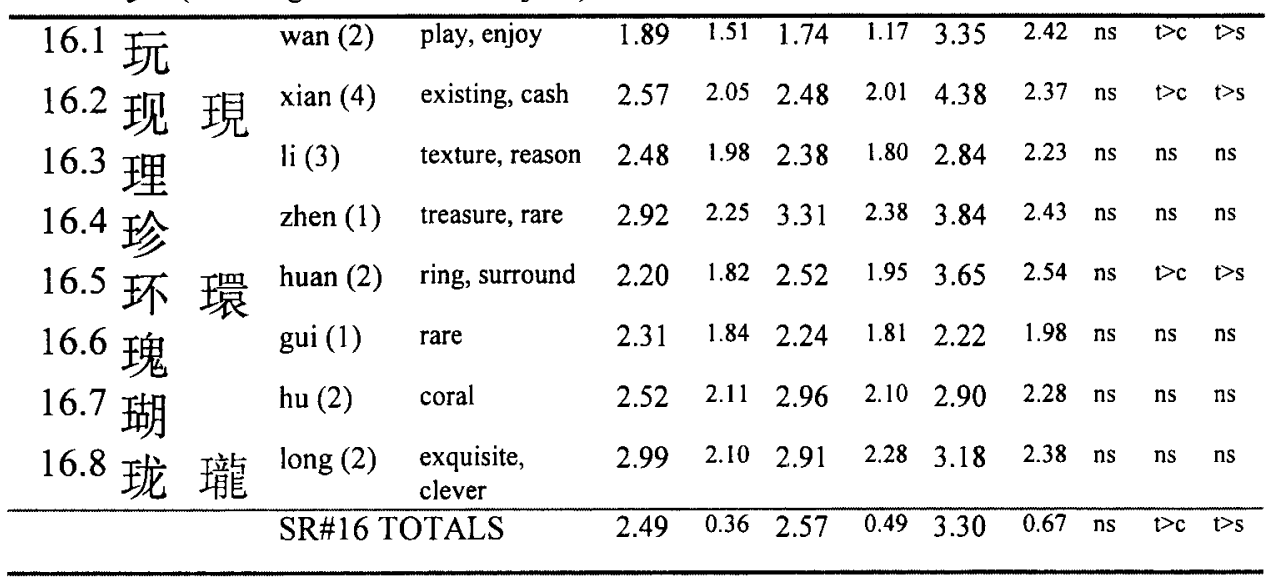

\begin{tabular}{|c|c|c|c|c|c|c|c|c|c|c|c|}
\hline 17.1 起 & qi (3) & direction & 3.73 & 2.20 & 3.84 & 2.10 & 3.34 & 2.37 & ns & ns & $\overline{\mathrm{ns}}$ \\
\hline 17.2 赶 趕 & $\operatorname{gan}(3)$ & catch up & 5.26 & 2.13 & 5.54 & 1.93 & 4.55 & 2.44 & ns & ns & $s>t$ \\
\hline 17.4 越 & yue (4) & jump over & 4.32 & 2.39 & 3.99 & 2.15 & 3.62 & 2.43 & ns & ns & ns \\
\hline 17.5 超 & chao (1) & surpass & 4.18 & 2.31 & 3.77 & 2.23 & 3.22 & 2.35 & ns & ns & ns \\
\hline 17.6 趁 & chen (4) & avail, while & 3.16 & 2.48 & 3.03 & 2.04 & 3.24 & 2.37 & ns & ns & ns \\
\hline 17.7 趟 & $\operatorname{tang}(4)$ & $\begin{array}{l}\text { number of } \\
\text { times (travel) }\end{array}$ & 5.09 & 2.10 & 5.21 & 1.80 & 4.18 & 2.46 & ns & $c>t$ & $s>t$ \\
\hline & \multicolumn{2}{|c|}{ SR\#17 TOTALS } & 4.29 & 0.80 & 4.23 & 0.95 & 3.69 & 0.55 & ns & $\mathrm{c}>\mathrm{t}$ & ns \\
\hline
\end{tabular}

18.0 全 (meaning associated with gold/metals)

\begin{tabular}{|c|c|c|c|c|c|c|c|c|c|c|c|c|}
\hline 18.2 错 & 錯 & cuo (4) & $\begin{array}{l}\text { wrong, } \\
\text { complex }\end{array}$ & 2.12 & 1.75 & 1.86 & 1.26 & 2.90 & 2.41 & ns & $t>c$ & $\mathrm{t}>\mathrm{s}$ \\
\hline 18.3 钟 & 鐘 & zhong (1) & bell, clock & 5.25 & 2.06 & 4.63 & 2.12 & 4.30 & 2.61 & ns & ns & ns \\
\hline 18.4 镜 & 鏡 & jing (4) & mirror, lens & 4.67 & 2.18 & 4.15 & 2.13 & 4.45 & 2.49 & ns & ns & ns \\
\hline 18.5 钉 & 金了 & $\operatorname{ding}(1)$ & nail/tack, press & 5.76 & 1.76 & 5.64 & 1.66 & 5.80 & 1.76 & ns & ns & ns \\
\hline 18.6 锈 & 銹 & xiu (4) & rust & 5.68 & 1.97 & 5.13 & 1.97 & 4.28 & 2.36 & ns & $c>t$ & ns \\
\hline 18.7 铐 & 銬 & kao (4) & handcuffs & 6.00 & 1.65 & 5.22 & 1.62 & 3.69 & 2.45 & $c>s$ & $c>t$ & $s>t$ \\
\hline 18.8 钧 & 俆 & jun (1) & $\begin{array}{l}\text { weight unit, } \\
\text { your }\end{array}$ & 3.88 & 2.40 & 3.64 & 2.13 & 2.18 & 1.97 & ns & $c>t$ & $s>t$ \\
\hline & & \multicolumn{2}{|c|}{ SR\#18 TOTALS } & 4.77 & 1.38 & 4.32 & 1.28 & 3.94 & 1.17 & ns & $\mathrm{c}>\mathrm{t}$ & $\mathrm{s}>\mathrm{t}$ \\
\hline
\end{tabular}


APPENDIX A (Continued)

\begin{tabular}{|c|c|c|c|c|c|c|c|c|c|c|c|c|c|}
\hline $\begin{array}{l}\text { SR\# } \\
\text { AoA }\end{array}$ & $\mathrm{S}$ & C & $\begin{array}{l}\text { Hanyu } \\
\text { Pinyin }\end{array}$ & $\begin{array}{l}\text { Meaning in } \\
\text { English }\end{array}$ & $\begin{array}{r}\text { Chir } \\
\text { Mean }\end{array}$ & $\begin{array}{l}\text { na } \\
\text { SDD } \\
\end{array}$ & $\begin{array}{l}\text { Sing } \\
\text { Mear }\end{array}$ & $\begin{array}{l}\text { pore } \\
\text { /SD } \\
\end{array}$ & $\begin{array}{r}\text { Taiw } \\
\text { Mean }\end{array}$ & & $\begin{array}{l}\mathrm{C} / \mathrm{S} \\
.05\end{array}$ & $\begin{array}{l}\mathrm{C} / \mathrm{T} \\
.05\end{array}$ & $\begin{array}{l}\mathrm{S} / \mathrm{T} \\
.05\end{array}$ \\
\hline 19.2 & 虾 & 蝦 & xia (1) & prawns & 6.13 & 1.36 & 5.31 & 2.02 & 4.80 & 2.19 & 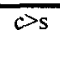 & $c>t$ & $\mathrm{~ns}$ \\
\hline 19.3 & 蚊 & & wen (2) & mosquito & 6.22 & 1.51 & 6.37 & 1.19 & 5.04 & 2.18 & ns & $c>t$ & $s>t$ \\
\hline 19.4 & 蛇 & & she (2) & snake & 5.85 & 1.57 & 5.39 & 2.03 & 4.96 & 2.36 & ns & $c>t$ & ns \\
\hline 19.5 & 虹 & & hong (2) & rainbow & 2.23 & 2.02 & 2.10 & 1.75 & 2.90 & 2.32 & ns & ns & ns \\
\hline 19.6 & 蜡 & 鼬 & la (4) & wax, candle & 2.72 & 2.04 & 2.33 & 1.95 & 3.30 & 2.57 & ns & ns & $t>s$ \\
\hline 19.7 & 蛾 & & e (2) & moth & 5.95 & 1.70 & 5.75 & 1.77 & 4.31 & 2.28 & ns & $c>t$ & $s>t$ \\
\hline 19.8 & 蛤 & & ha (2) & frog, toad & 5.75 & 1.82 & 4.89 & 2.03 & 4.58 & 2.31 & $c>s$ & $c>t$ & ns \\
\hline & & & SR\#19 T & TALS & 4.98 & 1.72 & 4.59 & 1.69 & 4.27 & 0.84 & $\mathrm{~ns}$ & $c>t$ & ns \\
\hline
\end{tabular}

20.0 (meaning associated with walking about)

\begin{tabular}{|c|c|c|c|c|c|c|c|c|c|c|c|c|}
\hline 20.1 & 过 過 & guo (4) & $\begin{array}{l}\text { across, pass } \\
\text { (time) }\end{array}$ & 3.32 & 2.27 & 3.44 & 2.16 & 3.35 & 2.37 & ns & $\mathrm{ns}$ & $\mathrm{ns}$ \\
\hline 20.2 & 运 運 & yun (4) & $\begin{array}{l}\text { movement, } \\
\text { fortune }\end{array}$ & 3.72 & 2.39 & 4.02 & 2.17 & 3.32 & 2.40 & ns & ns & ns \\
\hline 20.3 & 选 選 & xuan (3) & elect, pick & 2.78 & 1.89 & 3.04 & 1.95 & 2.44 & 2.03 & ns & ns & ns \\
\hline 20.4 & 达 達 & da (2) & $\begin{array}{l}\text { attain, } \\
\text { understand }\end{array}$ & 3.95 & 2.44 & 3.48 & 2.20 & 2.86 & 2.35 & ns & $c>t$ & ns \\
\hline 20.5 & 迫 & po (4) & force, press & 2.77 & 2.11 & 2.48 & 1.89 & 3.14 & 2.55 & ns & ns & ns \\
\hline 20.6 & 返 & fan (3) & return & 4.36 & 2.28 & 4.56 & 2.09 & 4.78 & 2.40 & ns & ns & ns \\
\hline 20.7 & 迁 & yu (1) & circuitous & 4.57 & 2.27 & 4.88 & 2.12 & 3.18 & 2.46 & ns & $c>t$ & $\mathrm{~s}>\mathrm{t}$ \\
\hline 20.8 & 遁 & hou (4) & meet by chance & 3.36 & 2.35 & 3.05 & 2.06 & 2.14 & 1.89 & ns & $c>t$ & $\mathrm{~s}>\mathrm{t}$ \\
\hline & & \multicolumn{2}{|c|}{ SR\#20 TOTALS } & 3.60 & 0.67 & 3.62 & 0.81 & 3.15 & 0.79 & ns & ns & ns \\
\hline
\end{tabular}

\begin{tabular}{|c|c|c|c|c|c|c|c|c|c|c|c|c|}
\hline 21.1 & 花 & hua (1) & $\begin{array}{l}\text { flower(y), } \\
\text { spend }\end{array}$ & 5.51 & 2.03 & 5.12 & 1.87 & 5.53 & 2.06 & $\mathrm{~ns}$ & ns & $\mathrm{ns}$ \\
\hline $21.2^{\mathrm{a}}$ & 节 節 & jie (2) & festival, node & 2.03 & 1.72 & 1.92 & 1.46 & 3.69 & 2.48 & $\mathrm{~ns}$ & $t>c$ & $\mathrm{p}>\mathrm{s}$ \\
\hline 21.3 & 苦 & ku (3) & bitter & 2.29 & 1.82 & 3.08 & 2.03 & 4.40 & 2.38 & $\mathrm{~s}>\mathrm{c}$ & $1>c$ & $\mathrm{t}>\mathrm{s}$ \\
\hline 21.4 & 贲 & huang (1) & waste, barren & 4.39 & 2.29 & 4.23 & 2.28 & 3.65 & 2.47 & $\mathrm{~ns}$ & ns & ns \\
\hline $21.5^{\mathrm{a}}$ & 范 艦 & fan (4) & example & 2.03 & 1.57 & 1.88 & 1.30 & 2.12 & 1.99 & ns & ns & ns \\
\hline 21.7 & 董 & dong (3) & director & 1.73 & 1.55 & 2.06 & 1.63 & 2.24 & 2.00 & ns & ns & ns \\
\hline & & \multicolumn{2}{|c|}{ SR\#21 TOTALS } & 3.00 & 1.56 & 3.05 & 1.36 & 3.61 & 1.30 & $\mathrm{~ns}$ & $\mathrm{~ns}$ & $\mathrm{~ns}$ \\
\hline
\end{tabular}




\section{APPENDIX A (Continued)}

\begin{tabular}{|c|c|c|c|c|c|c|c|c|c|c|c|c|c|}
\hline $\begin{array}{l}\text { SR\# } \\
\text { AoA }\end{array}$ & $\mathrm{S}$ & $\mathrm{C}$ & $\begin{array}{l}\text { Hanyu } \\
\text { Pinyin }\end{array}$ & $\begin{array}{l}\text { Meaning in } \\
\text { English }\end{array}$ & \multicolumn{2}{|c|}{$\begin{array}{c}\text { China } \\
\text { Mean /SD } \\
\end{array}$} & \multicolumn{2}{|c|}{$\begin{array}{l}\text { Singapore } \\
\text { Mean/SD }\end{array}$} & \multicolumn{2}{|c|}{$\begin{array}{c}\text { Taiwan } \\
\text { Mean/SD }\end{array}$} & $\begin{array}{l}\mathrm{C} / \mathrm{S} \\
.05\end{array}$ & $\begin{array}{l}\mathrm{C} / \mathrm{T} \\
.05\end{array}$ & $\begin{array}{l}\mathrm{S} / \mathrm{T} \\
.05\end{array}$ \\
\hline 22.0 & \multicolumn{13}{|c|}{$\rightarrow$ (meaning associated with houses) } \\
\hline 22.1 & 家 & & jia (1) & family, home & 2.28 & 1.82 & 4.28 & 2.45 & 5.32 & 2.27 & $\mathrm{c}>\mathrm{s}$ & $\overrightarrow{b c}$ & $t>s$ \\
\hline 22.2 & 客 & & ke (4) & $\begin{array}{l}\text { traveller, } \\
\text { objective }\end{array}$ & 3.16 & 2.38 & 3.80 & 2.22 & 4.69 & 2.32 & ns & $\mathbf{D}>\mathrm{c}$ & ns \\
\hline 22.3 & 实 & 實 & $\operatorname{shi}(2)$ & solid, real, seed & 2.96 & 2.43 & 2.05 & 1.42 & 3.65 & 2.48 & $c>s$ & ns & $D s$ \\
\hline 22.4 & 富 & & fu (4) & rich, wealthy & 3.36 & 2.60 & 3.50 & 2.26 & 5.14 & 2.27 & $\mathrm{~ns}$ & $D>c$ & $t>s$ \\
\hline $22.5^{\mathrm{a}}$ & 宾 & 濱 & $\operatorname{bin}(1)$ & guest & 2.73 & 2.06 & 3.80 & 2.26 & 2.51 & 2.09 & $\mathrm{~s}>\mathrm{c}$ & ns & $s>t$ \\
\hline 22.6 & 宋 & & song (4) & a dynasty & 1.93 & 1.58 & 2.88 & 2.07 & 3.82 & 2.50 & $s>c$ & $\triangleright c$ & $\mathrm{t}>\mathrm{s}$ \\
\hline 22.7 & 宠 & 籠 & chong (3) & dote & 2.80 & 2.24 & 3.75 & 2.37 & 4.84 & 2.59 & $\mathrm{~s}>\mathrm{c}$ & $\mathrm{t} .>\mathrm{c}$ & $t>s$ \\
\hline 22.8 & 容 & & rong (2) & $\begin{array}{l}\text { contain, } \\
\text { appearance }\end{array}$ & 2.78 & 2.13 & 2.73 & 1.89 & 3.62 & 2.38 & ns & ns & ns \\
\hline & & & $\overline{S R} \# 22 \mathrm{~T}$ & OTALS & 2.75 & 0.46 & 3.35 & 0.73 & 4.20 & 0.96 & ns & $\mathrm{ns}$ & $\mathrm{ns}$ \\
\hline
\end{tabular}

$23.0 \quad \ldots$ (meaning associated with fire)

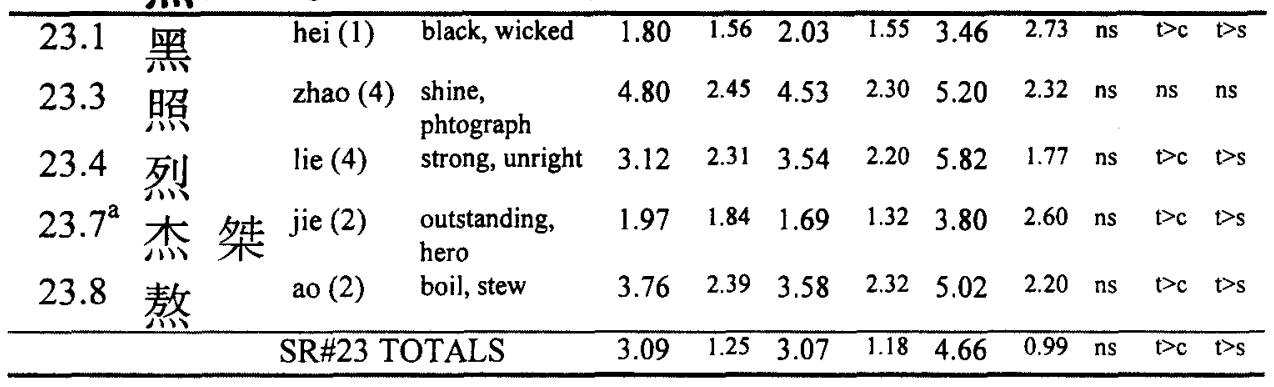

24.0 (meaning associated with smallness)

\begin{tabular}{|c|c|c|c|c|c|c|c|c|c|c|c|c|}
\hline $24.1^{a}$ & 觉 學 & jue (2) & feel & 2.73 & 2.10 & 3.02 & 2.04 & 3.16 & 2.54 & $\overline{\mathrm{ns}}$ & $\mathrm{ns}$ & $\overline{\mathrm{ns}}$ \\
\hline 24.2 & 常 & chang (2) & often & 1.81 & 1.66 & 1.68 & 1.06 & 2.71 & 2.26 & ns & $p c$ & t>s \\
\hline 24.3 & 堂 & $\operatorname{tang}(2)$ & main room & 2.47 & 1.99 & 3.34 & 2.18 & 3.71 & 2.44 & $s>c$ & $\mathbf{D}>\mathrm{c}$ & ns \\
\hline 24.5 & 尝 嘗 & chang (2) & taste & 3.03 & 2.57 & 1.84 & 1.27 & 4.33 & 2.49 & $\mathbf{c}>\mathbf{s}$ & $D C$ & $1>s$ \\
\hline 24.6 & 掌 & zhang (3) & hand, fist & 5.31 & 2.31 & 5.63 & 1.84 & 5.76 & 1.99 & ns & $\mathrm{ns}$ & ns \\
\hline 24.7 & 裳 & shang (4) & $\begin{array}{l}\text { clothing, } \\
\text { cloths }\end{array}$ & 5.75 & 1.99 & 6.02 & 1.65 & 4.88 & 2.27 & ns & $c>t$ & $s>t$ \\
\hline & & \multicolumn{2}{|c|}{ SR\#24 TOTALS } & 3.52 & 1.62 & 3.59 & 1.85 & 4.09 & 1.13 & ns & $>c$ & ns \\
\hline
\end{tabular}


APPENDIX A (Continued)

\begin{tabular}{|c|c|c|c|c|c|c|c|c|c|c|c|c|c|}
\hline $\begin{array}{l}\text { SR\# } \\
\text { AoA }\end{array}$ & $\mathrm{S}$ & $\mathrm{C}$ & $\begin{array}{l}\text { Hanyu } \\
\text { Pinyin }\end{array}$ & $\begin{array}{l}\text { Meaning in } \\
\text { English }\end{array}$ & \multicolumn{2}{|c|}{$\begin{array}{c}\text { China } \\
\text { Mean /SD } \\
\end{array}$} & \multicolumn{2}{|c|}{$\begin{array}{l}\text { Singapore } \\
\text { Mean/SD }\end{array}$} & \multicolumn{2}{|c|}{$\begin{array}{c}\text { Taiwan } \\
\text { Mean/SD }\end{array}$} & $\begin{array}{l}\mathrm{C} / \mathrm{S} \\
.05\end{array}$ & $\begin{array}{l}\mathrm{C} / \mathrm{T} \\
.05\end{array}$ & $\begin{array}{l}\mathrm{S} / \mathrm{T} \\
.05\end{array}$ \\
\hline 25.0 & & \multicolumn{12}{|c|}{ (meaning associated with enclosure) } \\
\hline 25.1 & 国 & 國 & guo (2) & country & 3.67 & 2.36 & 3.90 & 2.34 & 4.24 & 2.59 & ns & ns & ns \\
\hline 25.2 & 因 & & yin (1) & because & 1.84 & 1.72 & 2.28 & 1.80 & 3.16 & 2.59 & ns & $p c$ & $t>s$ \\
\hline 25.3 & 困 & & kun (4) & $\begin{array}{l}\text { surrounded, } \\
\text { tired }\end{array}$ & 4.35 & 2.64 & 5.30 & 2.03 & 5.63 & 2.08 & $s>c$ & $t>c$ & ns \\
\hline 25.4 & 团 & 雷 & tuan (2) & a society & 3.70 & 2.55 & 3.68 & 2.18 & 4.41 & 2.36 & ns & $\mathrm{ns}$ & ns \\
\hline 25.6 & 固 & & gu (4) & firmly, solid & 4.77 & 2.37 & 3.44 & 2.24 & 5.37 & 2.01 & $>s$ & ns & $\triangleright s$ \\
\hline 25.7 & 风 & & qiu (2) & $\begin{array}{l}\text { imprison, } \\
\text { convict }\end{array}$ & 5.77 & 1.94 & 6.37 & 1.43 & 6.63 & 1.28 & $\mathrm{~s}>\mathrm{c}$ & $\mathrm{t}>\mathrm{c}$ & ns \\
\hline \multirow[t]{2}{*}{25.8} & 囫 & & hu (2) & swallow whole & 4.09 & 2.38 & 3.76 & 2.30 & 2.70 & 2.34 & ns & $\mathbf{D} \mathbf{c}$ & $s>t$ \\
\hline & & & \multicolumn{2}{|c|}{ SR\#25 TOTALS } & 4.03 & 1.21 & 4.10 & 1.33 & 4.59 & 1.39 & ns & $\mathbf{p}>\mathrm{c}$ & ns \\
\hline
\end{tabular}

\begin{tabular}{|c|c|c|c|c|c|c|c|c|c|c|c|c|}
\hline 26.2 & 病 & bing (4) & ill, disease & 5.95 & 1.76 & 4.93 & 2.30 & 4.49 & 2.46 & $c>s$ & $c>t$ & ns \\
\hline 26.3 & 疼 & teng (2) & ache, be fond of & 5.69 & 1.85 & 4.23 & 2.38 & 4.41 & 2.40 & $c>s$ & $c>t$ & $\mathrm{~ns}$ \\
\hline 26.5 & 疲 & pi (2) & exhausted & 5.70 & 1.69 & 4.88 & 2.27 & 4.47 & 2.39 & $c>s$ & $c>t$ & ns \\
\hline 26.6 & 疾 & $\mathrm{ji}(2)$ & sickness, abhor & 5.81 & 1.71 & 5.25 & 1.91 & 4.73 & 2.24 & ns & $c>t$ & ns \\
\hline 26.7 & 症 & zheng (4) & illness & 5.83 & 1.65 & 5.48 & 1.78 & 4.20 & 2.45 & ns & $c>t$ & $s>t$ \\
\hline 26.8 & 㾉 & $\mathrm{da}(2)$ & carbuncle & 4.17 & 2.19 & 4.54 & 2.13 & 2.29 & 1.77 & ns & $c>t$ & $s>t$ \\
\hline & & \multicolumn{2}{|c|}{ SR\#26 TOTALS } & 5.53 & 0.67 & 4.89 & 0.46 & 4.10 & 0.90 & $\mathrm{c}>\mathrm{s}$ & $c>t$ & $s>t$ \\
\hline
\end{tabular}

\begin{tabular}{|c|c|c|c|c|c|c|c|c|c|c|c|c|}
\hline 27.2 & 想 & xiang (3) & suppose, think & 6.36 & 1.20 & 6.23 & 1.15 & 5.44 & 2,04 & ns & $c>t$ & $s>t$ \\
\hline 27.3 & 急 & ji (2) & $\begin{array}{l}\text { impatient, } \\
\text { worry }\end{array}$ & 5.77 & 1.76 & 5.80 & 1.53 & 4.75 & 2.20 & ns & $c>t$ & $\mathrm{~s}>\mathrm{t}$ \\
\hline 27.4 & 志 & zhi (4) & $\begin{array}{l}\text { aspiration, } \\
\text { annals }\end{array}$ & 5.59 & 1.90 & 5.63 & 1.73 & 5.69 & 1.85 & ns & ns & ns \\
\hline 27.5 & 因 & en (1) & kindness & 5.48 & 1.69 & 5.74 & 1.50 & 5.66 & 1.80 & ns & ns & ns \\
\hline 27.6 & 恶 惡 & e (4) & vice, fierce & 5.54 & 1.84 & 4.98 & 2.13 & 5.04 & 2.22 & $\mathrm{~ns}$ & ns & ns \\
\hline 27.7 & 恋 戀 & lian (4) & $\begin{array}{l}\text { love, feel } \\
\text { attached }\end{array}$ & 5.91 & 1.68 & 5.78 & 1.47 & 4.80 & 2.37 & $\mathrm{~ns}$ & $c>t$ & $s>t$ \\
\hline 27.8 & 志 & te (4) & $\begin{array}{l}\text { (mentally) } \\
\text { disturbed }\end{array}$ & 5.19 & 2.17 & 5.82 & 1.58 & 5.41 & 2.38 & ns & ns & ns \\
\hline \multicolumn{4}{|c|}{ SR\#27 TOTALS } & 5.69 & 0.37 & 5.71 & 0.37 & 5.26 & 0.39 & ns & $\mathrm{ns}$ & ns \\
\hline
\end{tabular}


APPENDIX A (Continued)

\begin{tabular}{lllllllllll}
\hline SR\# & & & Hanyu & Meaning in & China & Singapore & Taiwan & C/S & C/T & S/T \\
AoA & $\mathrm{S}$ & $\mathrm{C}$ & Pinyin & English & Mean $/ \mathrm{SD}$ & Mean/SD & Mean/SD & .05 & .05 & .05 \\
\hline
\end{tabular}

$28.0 \Gamma$ (meaning associated with wideness, vastness)

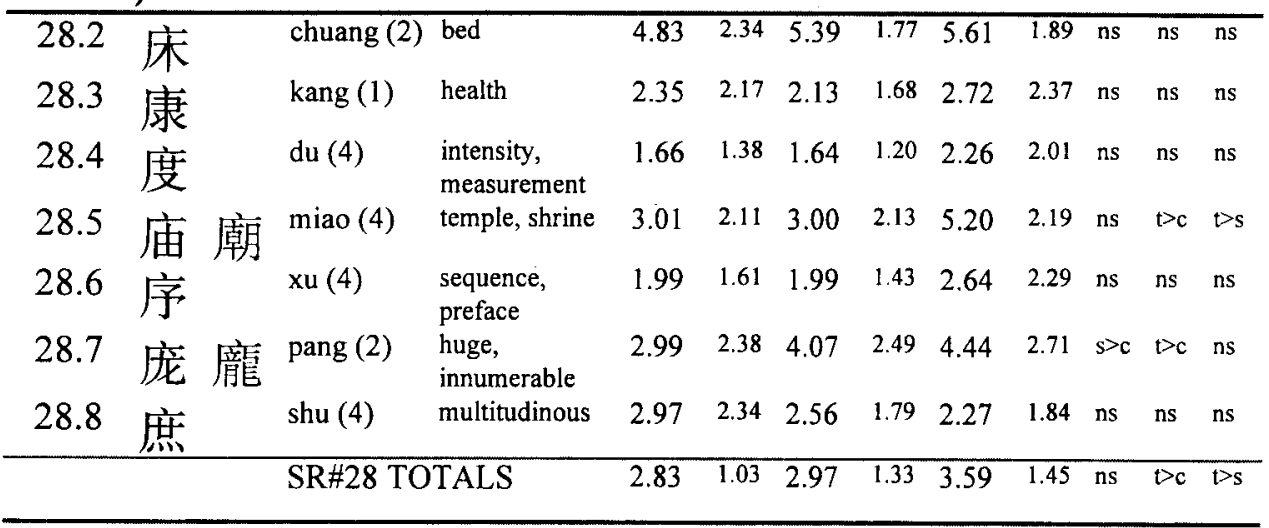

$29.0 \quad \bar{\lambda}$ (meaning associated with showing to others)

\begin{tabular}{|c|c|c|c|c|c|c|c|c|c|c|c|c|}
\hline 29.2 & 视 視 & shi (4) & look at, inspect & 4.45 & 2.47 & 5.24 & 2.13 & 5.90 & 1.76 & ns & $\overrightarrow{p c}$ & ns \\
\hline 29.3 & 神 & shen (2) & deity, spirit & 2.81 & 2.14 & 3.85 & 2.40 & 3.90 & 2.57 & $s>c$ & $t>c$ & $\mathrm{~ns}$ \\
\hline 29.4 & 福 & fu (2) & good fortune & 2.93 & 2.21 & 3.64 & 2.22 & 3.96 & 2.56 & ns & $\mathfrak{t}>\mathrm{c}$ & $\mathrm{ns}$ \\
\hline 29.5 & 社 & she (4) & agency, society & 2.37 & 1.83 & 2.35 & 1.69 & 3.98 & 2.36 & ns & $\mathbf{l}>\mathbf{c}$ & $p s$ \\
\hline 29.8 & 祠 & ci (2) & ancestral hall & 2.77 & 2.03 & 4.08 & 2.15 & 4.51 & 2.40 & $s>c$ & $\mathbf{l}>\mathbf{c}$ & $\mathrm{ns}$ \\
\hline & & \multicolumn{2}{|c|}{ SR\#29 TOTALS } & 3.07 & 0.80 & 3.83 & 1.03 & 4.45 & 0.85 & $s>c$ & $D C$ & $\mathrm{~ns}$ \\
\hline
\end{tabular}

\begin{tabular}{|c|c|c|c|c|c|c|c|c|c|c|c|c|}
\hline & & & & & & & & & & & & \\
\hline 30.2 & 物 & wu (4) & $\begin{array}{l}\text { substance, } \\
\text { thing }\end{array}$ & 3.52 & 2.56 & 3.92 & 2.15 & 3.73 & 2.45 & $\mathrm{~ns}$ & $\mathrm{~ns}$ & ns \\
\hline 30.4 & 特 & te (4) & special, spy & 1.75 & 1.58 & 1.82 & 1.32 & 2.66 & 2.23 & ns & $1>c$ & $t>s$ \\
\hline 30.5 & 牧 & $\mathrm{mu}(4)$ & herd, tend & 5.60 & 1.98 & 4.90 & 2.14 & 4.02 & 2.44 & ns & $c>t$ & ns \\
\hline 30.6 & 牲 & sheng (1) & $\begin{array}{l}\text { sacrifice, } \\
\text { liverstock }\end{array}$ & 5.51 & 1.95 & 4.64 & 2.16 & 4.54 & 2.35 & $c>s$ & $c>t$ & ns \\
\hline 30.8 & 牡 & $\mathrm{mu}(3)$ & male & 2.25 & 1.72 & 3.96 & 2.30 & 2.64 & 2.06 & $\mathrm{~s}>\mathrm{c}$ & ns & $\mathrm{s}>\mathrm{t}$ \\
\hline \multicolumn{4}{|c|}{ SR\#30 TOTALS } & 3.73 & 1.79 & 3.85 & 1.21 & 3.52 & 0.84 & $\mathrm{~ns}$ & ns & ns \\
\hline
\end{tabular}


APPENDIX A (Continued)

\begin{tabular}{lllllllllll}
\hline SR\# & & & Hanyu & Meaning in & China & Singapore & Taiwan & C/S & C $/ T$ & S/T \\
AoA & $S$ & $C$ & Pinyin & English & Mean $/ S D$ & Mean/SD & Mean/SD & .05 & .05 & .05 \\
\hline
\end{tabular}

$31.0 \rightleftharpoons$ (meaning associated with corpse, image)

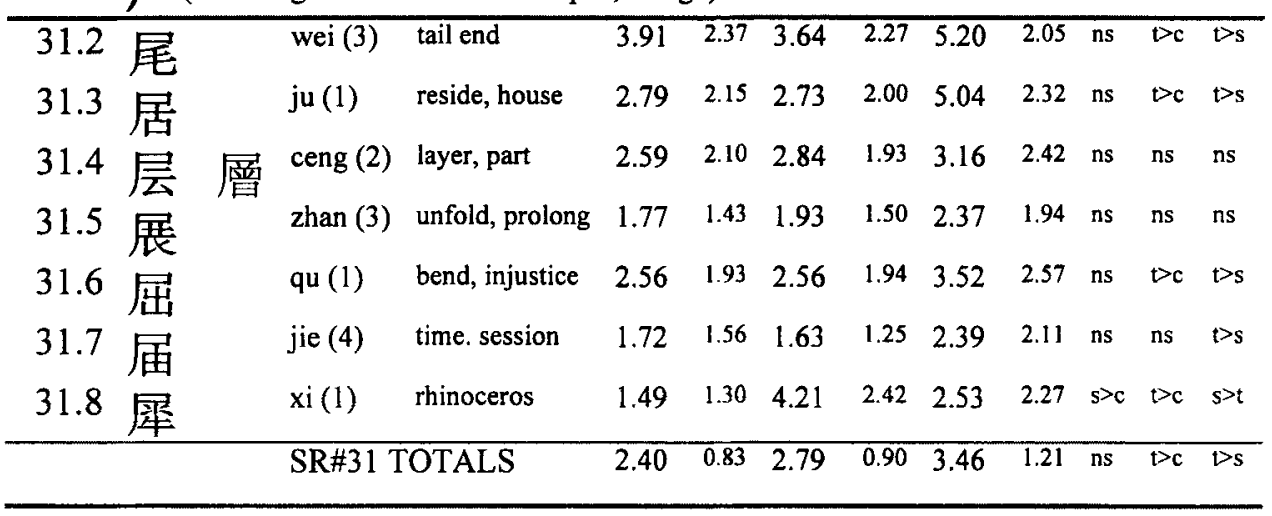

$32.0 \square$ (meaning associated with entrance/exit)

\begin{tabular}{|c|c|c|c|c|c|c|c|c|c|c|c|c|c|}
\hline 32.2 & 问 & 問 & wen (4) & $\begin{array}{l}\text { inquire, } \\
\text { interrogate }\end{array}$ & 5.30 & 2.27 & 5.77 & 1.88 & 6.04 & 1.71 & $\overline{\mathrm{ns}}$ & ns & ns \\
\hline 32.4 & 闲 & 橗 & xian (2) & idle, leisure & 2.73 & 2.08 & 3.13 & 2.07 & 3.94 & 2.54 & ns & $p c$ & ns \\
\hline 32.5 & 忍 & 悶 & $\operatorname{men}(1)$ & $\begin{array}{l}\text { stuffy, shut } \\
\text { indoors }\end{array}$ & 6.30 & 1.51 & 6.22 & 1.36 & 6.33 & 1.40 & ns & ns & ns \\
\hline 32.6 & 闭 & 閉 & bi (4) & shut, obstruct & 4.37 & 2.34 & 4.24 & 2.31 & 4.61 & 2.52 & ns & ns & ns \\
\hline 32.7 & 鸟 & 闖 & chuang (3) & dash, change & 5.53 & 1.87 & 5.00 & 2.20 & 5.84 & 1.62 & ns & ns & $t>s$ \\
\hline 32.8 & 闽 & 虽 & $\min (3)$ & $\begin{array}{l}\text { Fujian } \\
\text { Province }\end{array}$ & 1.93 & 1.52 & 1.72 & 1.31 & 2.31 & 2.04 & ns & ns & ns \\
\hline & & \multicolumn{3}{|c|}{ SR\#32 TOTALS } & 4.36 & 1.71 & 4.35 & 1.69 & 4.85 & 1.54 & as & ns & ns \\
\hline
\end{tabular}

\begin{tabular}{|c|c|c|c|c|c|c|c|c|c|c|c|c|}
\hline 33.2 & 加 & iia (4) & shelf, fend off & 5.21 & 2.01 & 470 & 2.13 & 5.27 & 2.15 & $\mathrm{~ns}$ & ns & ns \\
\hline 334 & & $\operatorname{li}(2)$ & pear & 572 & 1.96 & 396 & 2.11 & 414 & 2.51 & $c>s$ & $c>t$ & ns \\
\hline (3.4. & 梨 & & & & & 0 & & & & & & IIS \\
\hline 33.5 & 集 & ji (2) & gather, & 2.29 & 1.89 & 2.51 & 1.77 & 5.08 & 2.33 & ns & $t>c$ & $>s$ \\
\hline 33.6 & 染 & $\operatorname{ran}(3)$ & $\begin{array}{l}\text { dye, } \\
\text { contaminate }\end{array}$ & 2.87 & 2.25 & 3.17 & 1.96 & 4.84 & 2.36 & ns & $>c$ & $>s$ \\
\hline 33.7 & 梁 & liang (2) & $\begin{array}{l}\text { roof beam, } \\
\text { bridge }\end{array}$ & 5.20 & 2.05 & 4.35 & 2.24 & 3.02 & 2.36 & $c>s$ & $c>t$ & $s>t$ \\
\hline & & \multicolumn{2}{|c|}{ SR\#33 TOTALS } & 4.26 & 1.56 & 3.74 & 0.89 & 4.47 & 0.92 & ns & $\mathrm{ns}$ & ns \\
\hline
\end{tabular}




\section{APPENDIX A (Continued)}

\begin{tabular}{lllllllllll}
\hline SR\# & & & Hanyu & Meaning in & China & Singapore & Taiwan & C/S & $\mathrm{C} / \mathrm{T}$ & $\mathrm{S} / \mathrm{T}$ \\
$\mathrm{AoA}$ & $\mathrm{S}$ & $\mathrm{C}$ & Pinyin & English & Mean $/ \mathrm{SD}$ & Mean/SD & Mean/SD & .05 & .05 & .05 \\
\hline
\end{tabular}

34.01 (meaning associated with walking slowly)

\begin{tabular}{|c|c|c|c|c|c|c|c|c|c|c|c|}
\hline 34.1 很 & hen (3) & very, quite & 1.93 & 1.61 & 1.94 & 1.52 & 2.48 & 2.17 & ns & $\overline{\mathrm{ns}}$ & ns \\
\hline 34.3 往 & wang (3) & go, toward & 3.32 & 2.18 & 3.27 & 2.04 & 3.45 & 2.50 & ns & ns & ns \\
\hline 34.4 待 & dai (4) & wait, entertain & 3.73 & 2.28 & 3.64 & 2.01 & 3.57 & 2.41 & ns & ns & ns \\
\hline 34.5 徒 & tu $(2)$ & $\begin{array}{l}\text { on foot, } \\
\text { follower }\end{array}$ & 3.60 & 2.35 & 3.87 & 2.16 & 4.22 & 2.47 & ns & ns & ns \\
\hline 34.6 征 & zheng (1) & go on journey & 3.01 & 2.15 & 2.82 & 1.92 & 4.34 & 2,38 & ns & $\mathrm{t}>\mathrm{c}$ & $\mathrm{t}>\mathrm{s}$ \\
\hline 34.7 彼 & bi (3) & that, another & 3.75 & 2.40 & 3.88 & 2.28 & 3.12 & 2.39 & ns & ns & ns \\
\hline 34.8 彷 & pang (2) & hesitate & 3.08 & 2.19 & 3.20 & 2.16 & 2.37 & 2.14 & ns & ns & ns \\
\hline & \multicolumn{2}{|c|}{ SR\#34 TOTALS } & 3.20 & 0.64 & 3.23 & 0.69 & 3.36 & 0.77 & ns & ns & ns \\
\hline
\end{tabular}

35.0 (meaning associated with bamboo)

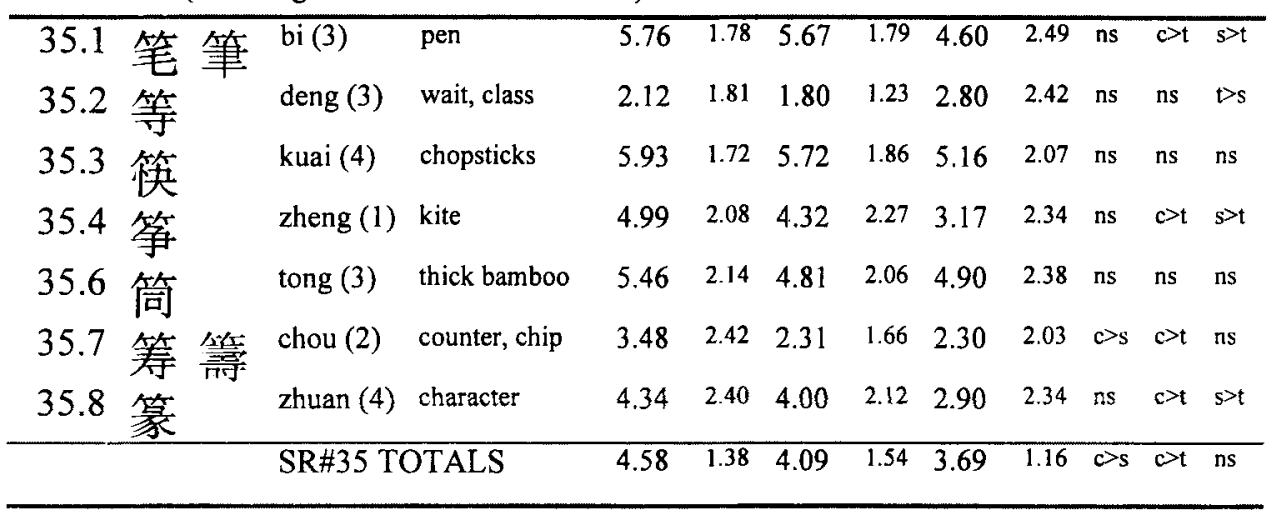

36.0 $\quad$ 日 (meaning associated with the sun)

\begin{tabular}{|c|c|c|c|c|c|c|c|c|c|c|c|c|}
\hline 36.3 & 暗 & an (4) & dim, unciear & 4.65 & 2.24 & 4.31 & 2.38 & 4.14 & 2.48 & $\mathrm{~ns}$ & $\mathrm{~ns}$ & $\mathrm{~ns}$ \\
\hline 36.4 & 晴 & qing (2) & fine, clear & 6.00 & 1.74 & 6.42 & 1.30 & 5.82 & 1.80 & ns & ns & $\mathrm{ns}$ \\
\hline 36.5 & 晓 曉 & xiao (3) & dawn, inform & 5.04 & 2.29 & 4.70 & 2.27 & 4.68 & 2.29 & ns & ns & ns \\
\hline 36.6 & 映 & ying (4) & reflect, mirror & 5.11 & 2.00 & 4.32 & 2.15 & 4.65 & 2.34 & ns & $\mathrm{ns}$ & $\mathrm{ns}$ \\
\hline 36.7 & 旰 & wang (4) & prosperous & 4.01 & 2.23 & 4.56 & 1.91 & 5.37 & 2.15 & ns & $\triangleright c$ & ns \\
\hline 36.8 & 晖 腪 & hui (1) & sunlight & 5.07 & 2.21 & 5.01 & 2.07 & 4.76 & 2.25 & ns & ns & ns \\
\hline & & \multicolumn{2}{|c|}{ SR\# 36 TOTALS } & 4.98 & 0.65 & 4.89 & 0.80 & 4.90 & 0.60 & ns & ns & $\overline{n s}$ \\
\hline & & \multicolumn{2}{|c|}{ GRAND TOTALS } & 4.22 & 0.77 & 4.15 & 0.81 & 4.15 & 1.18 & ns & ns & ns \\
\hline
\end{tabular}

a semantic radical changed 
APPENDIX B

Phonetic Regularity Ratings

Means and Standard Deviations (7-Point Scale) With One-Way Analysis of Variance (Tukey a) Results Between China (C), Singapore (S), and Taiwan (T) Subjects

\section{SAME PHONEMES/SAME TONE (SPST)}

\begin{tabular}{|c|c|c|c|c|c|c|c|c|c|c|c|c|c|c|}
\hline $\begin{array}{l}\overline{P R} \\
\#\end{array}$ & $\begin{array}{l}\text { Simp } \\
\text { Char }\end{array}$ & $\begin{array}{l}\text { Com } \\
\text { Char }\end{array}$ & $\begin{array}{l}\text { Hanyu } \\
\text { Pinyin }\end{array}$ & $\begin{array}{l}\text { Phon } \\
\& \mathrm{Ha}\end{array}$ & $\begin{array}{l}\text { tic Radical } \\
\text { nyu Pinyin }\end{array}$ & $\begin{array}{r}\text { Ch } \\
\text { Mear }\end{array}$ & & $\begin{array}{l}\text { Singa } \\
\text { Meas }\end{array}$ & $\begin{array}{l}\text { ore } \\
\text { /SD } \\
\end{array}$ & $\begin{array}{l}\text { Taiv } \\
\text { Mear }\end{array}$ & & $\begin{array}{l}\mathrm{C} / \mathrm{S} \\
.05 \\
\end{array}$ & $\begin{array}{l}\mathrm{C} / \mathrm{T} \\
.05 \\
\end{array}$ & $\begin{array}{l}\mathrm{S} / \mathrm{T} \\
.05 \\
\end{array}$ \\
\hline 1 & 理 & & $\operatorname{li}(3)$ & 里 & $\operatorname{li(3)}$ & 6.73 & 0.86 & 6.68 & 0.88 & 6.71 & 0.90 & ns & ns & ns \\
\hline 2 & 清 & & qing(1) & $\overline{\text { 青 }}$ & qing(1) & 6.80 & 0.56 & 6.77 & 0.74 & 6.84 & 0.37 & ns & ns & ns \\
\hline 3 & 供 & & gong(4) & 共 & gong(4) & 6.46 & 1.25 & 5.99 & 1.16 & 5.92 & 1.21 & ns & $c>t$ & ns \\
\hline 4 & 碑 & & bei(1) & 卑 & bei(1) & 5.94 & 1.76 & 5.10 & 2.12 & 6.39 & 1.36 & $c>s$ & ns & $p s$ \\
\hline 5 & 胞 & & bao(1) & 包 & bao(1) & 6.42 & 1.38 & 6.16 & 1.49 & 6.76 & 0.43 & ns & $\mathrm{ns}$ & $p s$ \\
\hline 6 & 返 & & fan(3) & 反 & $\operatorname{fan}(3)$ & 6.66 & 1.04 & 6.52 & 0.93 & 6.80 & 0.45 & ns & ns & $\mathrm{ns}$ \\
\hline 7 & 抬 & & $\operatorname{tai}(2)$ & 台 & $\operatorname{tai}(2)$ & 6.75 & 0.84 & 6.77 & 0.64 & 6.80 & 0.45 & ns & ns & ns \\
\hline 8 & 踪 & & zong(1) & 宗 & zong(1) & 6.63 & 0.87 & 6.77 & 0.54 & 6.69 & 0.55 & ns & ns & ns \\
\hline $9^{\mathbf{a}, \mathbf{c}}$ & 绘 & 繪 & hui(4) & 会 & hui(4) & 6.70 & 0.87 & 6.74 & 0.71 & 6.61 & 1.06 & ns & ns & ns \\
\hline 10 & 油 & & you(2) & 由 & you(2) & 6.87 & 0.67 & 6.81 & 0.79 & 6.59 & 1.00 & ns & ns & ns \\
\hline 11 & 牲 & & sheng(1) & 生 & sheng(1) & 6.49 & 1.28 & 6.04 & 1.66 & 6.39 & 1.40 & ns & ns & ns \\
\hline 12 & 叮 & & $\operatorname{ding}(1)$ & $\bar{J}$ & $\operatorname{ding}(1)$ & 6.90 & 0.35 & 6.89 & 0.36 & 6.88 & 0.33 & ns & ns & ns \\
\hline $13^{c}$ & 锈 & 銹 & $\operatorname{xiu}(4)$ & 秀 & $\operatorname{xiu}(4)$ & 6.54 & 1.20 & 6.63 & 0.83 & 6.53 & 0.97 & ns & ns & ns \\
\hline 14 & 咚 & & dong(1) & 冬 & dong(1) & 6.84 & 0.69 & 6.66 & 0.85 & 6.65 & 0.87 & ns & ns & ns \\
\hline 15 & 趾 & & zhi(3) & 佔 & zhi(3) & 6.63 & 0.90 & 5.73 & 1.64 & 6.78 & 0.91 & $c>s$ & ns & $t>s$ \\
\hline $16^{\mathrm{a}}$ & 珑 & 瓏 & $\operatorname{long}(2)$ & 龙 & long(2) & 6.88 & 0.41 & 6.82 & 0.51 & 6.65 & 0.96 & ns & ns & ns \\
\hline 17 & 消 & & xiao(1) & 肖 & xiao(1) & 6.28 & 1.33 & 5.35 & 1.41 & 5.33 & 1.80 & $>s$ & $c>t$ & ns \\
\hline 18 & 肝 & & $\operatorname{gan}(1)$ & 干 & $\operatorname{gan}(1)$ & 6.52 & 0.89 & 6.55 & 1.05 & 6.55 & 1.24 & ns & ns & ns \\
\hline 19 & 猖 & & chang(1) & 昌 & chang(1) & 6.79 & 0.48 & 6.64 & 0.77 & 6.47 & 1.40 & ns & ns & ns \\
\hline 20 & 沫 & & $\operatorname{mo}(4)$ & 末 & $\operatorname{mo}(4)$ & 6.55 & 1.03 & 6.38 & 0.95 & 6.49 & 1.03 & ns & ns & ns \\
\hline $21^{\mathrm{a}}$ & 犹 & 猶 & you(2) & 尤 & you(2) & 6.64 & 0.87 & 6.49 & 0.78 & 5.46 & 2.04 & ns & $c>t$ & $s>t$ \\
\hline $22^{\mathrm{a}}$ & 伦 & 倫 & $\operatorname{lun}(2)$ & $\hat{\imath}$ & $\operatorname{lun}(2)$ & 6.60 & 1.10 & 6.36 & 118 & 5.65 & 2.01 & ns & $c>t$ & $s>t$ \\
\hline $23^{c}$ & 缔 & 締 & $\operatorname{di}(4)$ & 帝 & $\mathrm{di}(4)$ & 6.39 & 1.40 & 6.43 & 1.00 & 6.29 & 1.17 & ns & ns & ns \\
\hline 24 & 蚊 & & wen(2) & 文 & wen(2) & 6.39 & 0.87 & 5.53 & 1.60 & 6.88 & 0.33 & ns & $D c$ & $t>s$ \\
\hline & & & SPST T & $\overline{\text { DTA] }}$ & & 6.59 & 0.45 & 6.36 & 0.48 & 6.46 & 0.52 & $c>s$ & ns & \\
\hline
\end{tabular}


APPENDIX B (Continued)

\section{SAME PHONEMES/DIFFERENT TONE (SPDT)}

\begin{tabular}{|c|c|c|c|c|c|c|c|c|c|c|c|c|c|}
\hline \multirow{2}{*}{$\begin{array}{l}\text { PR } \\
\# \\
25\end{array}$} & \multirow{2}{*}{$\begin{array}{l}\text { Simp } \\
\text { Char } \\
\text { 唱 }\end{array}$} & \multirow[t]{2}{*}{$\begin{array}{l}\text { Com } \\
\text { Char }\end{array}$} & \multirow{2}{*}{$\begin{array}{l}\text { Hanyu } \\
\text { Pinyin } \\
\text { chang(4) }\end{array}$} & $\begin{array}{l}\text { Phonetic Radical } \\
\text { \& Hanyu Pinyin }\end{array}$ & \multicolumn{2}{|c|}{$\begin{array}{c}\text { China } \\
\text { Mean/SD }\end{array}$} & \multicolumn{2}{|c|}{$\begin{array}{l}\text { Singapore } \\
\text { Mean/SD }\end{array}$} & \multicolumn{2}{|c|}{$\begin{array}{c}\text { Taiwan } \\
\text { Mean/SD }\end{array}$} & \multirow{2}{*}{$\begin{array}{l}\mathrm{C} / \mathrm{S} \\
.05 \\
\mathrm{~ns}\end{array}$} & \multirow{2}{*}{$\begin{array}{l}\mathrm{C} / \mathrm{T} \\
.05 \\
\mathrm{~ns}\end{array}$} & \multirow{2}{*}{$\begin{array}{l}\mathrm{S} / \mathrm{T} \\
.05 \\
\mathrm{~ns}\end{array}$} \\
\hline & & & & chang(1) & 5.85 & 0.92 & 5.53 & 1.01 & 5.55 & 1.12 & & & \\
\hline $26^{\mathrm{c}}$ & 较 & 較 & jiao(4) & jiao(1) & 5.80 & 0.85 & 5.26 & 1.14 & 5.35 & 1.31 & $c s$ & $\mathrm{~ns}$ & ns \\
\hline $27^{b}$ & 胜 & 勝 & sheng(4) & sheng(1) & 5.70 & 1.02 & 5.30 & 1.09 & 1.43 & 1.24 & $\mathrm{~ns}$ & $c>t$ & $\mathrm{~s}>\mathrm{t}$ \\
\hline 28 & 抹 & & $\mathrm{mo}(3)$ & $\operatorname{mo}(4$ & 5.76 & 1.27 & 5.55 & 1.55 & 5.18 & 1.63 & ns & ns & ns \\
\hline $29^{\mathbf{a}, \mathbf{c}}$ & 论 & 論 & $\operatorname{lun}(4)$ & $\operatorname{lun}(2)$ & 5.72 & 1.33 & 5.52 & 1.17 & 4.69 & 1.91 & ns & $\gg t$ & $s>t$ \\
\hline $30^{\mathrm{a}}$ & 拢 & 攏 & long(3) & $\operatorname{long}(2)$ & 5.70 & 1.33 & 5.63 & 1.18 & 6.00 & 0.69 & ns & ns & $\mathrm{ns}$ \\
\hline $31^{\mathrm{a}}$ & 优 & 優 & you( & 尤 you(2) & 5.94 & 1.20 & 6.23 & 0.87 & 5.94 & 2.09 & ns & ns & ns \\
\hline 32 & 嫖 & & piao(2) & 票 piao(4) & 5.87 & 1.07 & 5.37 & 1.01 & 5.18 & 1.61 & $c>s$ & $c>t$ & ns \\
\hline $33^{c}$ & 饱 & 飽 & bao(3) & 包 bao(1) & 6.13 & 0.78 & 5.74 & 1.07 & 5.80 & 1.04 & $c>s$ & ns & ns \\
\hline $34^{c}$ & 讪 & 言山 & shant & $\operatorname{shan}(1)$ & 4.49 & 2.08 & 4.32 & 2.19 & 4.76 & 1.91 & ns & ns & ns \\
\hline 35 & 村 & & $\operatorname{cun}(1)$ & 计 $\operatorname{cun}(4$ & 5.72 & 0.97 & 4.90 & 1.49 & 5.00 & 1.70 & $\mathrm{c}>\mathrm{s}$ & $c>t$ & ns \\
\hline 36 & 柚 & & you(4) & 由 you(2) & 5.11 & 2.31 & 5.25 & 1.76 & 5.02 & 1.71 & ns & ns & ns \\
\hline 37 & 旺 & & wang( & wang & 5.64 & 1.07 & 5.25 & 1.20 & 5.06 & 1.50 & ns & $c>t$ & ns \\
\hline $38^{\mathrm{c}}$ & 订 & 唁丁 & $\operatorname{ding}(4)$ & $\operatorname{ding}(1)$ & 5.81 & 1.18 & 5.45 & 1.19 & 5.33 & 1.42 & ns & ns & ns \\
\hline $39^{\mathrm{c}}$ & 饭 & 飯 & $\operatorname{fan}(4)$ & $\bar{反}^{\mathrm{fan}(3)}$ & 5.70 & 0.90 & 5.25 & 1.10 & 5.06 & 1.62 & ns & $\mathbf{c}>\mathbf{t}$ & ns \\
\hline 40 & 庇 & & bi(4) & 比 & 73 & 1.69 & 4.93 & 1.47 & 4.96 & 1.79 & $\mathrm{~ns}$ & ns & ns \\
\hline 41 & 瑰 & & $\operatorname{gui}(1 / 4)$ & 鬼 gui(3) & 48 & 1.11 & 5.08 & 1.31 & 3.94 & 2.23 & ns & $c>t$ & $s>t$ \\
\hline 42 & 姑 & & $\mathrm{gu}(1)$ & 古 $\mathrm{gu}(3)$ & 82 & 0.92 & 5.48 & 1.20 & 5.27 & 1.51 & ns & $c>t$ & ns \\
\hline 43 & 晴 & & $\alpha \sigma^{\prime}$ & 青 qing & 43 & 1.48 & 4.92 & 1.34 & 5.35 & 1.35 & $\mathrm{~ns}$ & $\mathrm{~ns}$ & ns \\
\hline 44 & 粽 & & zong(3/4) & 宗 zon & 6.24 & 1.10 & 5.74 & 0.83 & 5.78 & 1.12 & $c>s$ & $>t$ & ns \\
\hline 45 & 胎 & & $\operatorname{tai}(1)$ & 台 ${ }^{\operatorname{tai}(2)}$ & 99 & 0.86 & 5.22 & 1.46 & 5.18 & 1.66 & $c>s$ & $c>t$ & ns \\
\hline 46 & 拱 & & gong(3) & 共 gong & 28 & 1.43 & 4.71 & 1.58 & 4.96 & 1.83 & ns & ns & ns \\
\hline $47^{\mathrm{c}}$ & 记 & 記 & $\mathrm{ji}(4)$ & $己^{\mathrm{ji}(3)}$ & 4.58 & 2.00 & 4.38 & 1.85 & 4.18 & 2.15 & ns & ns & ns \\
\hline $48^{c}$ & 饼 & 餅 & bing(3) & 并 bing(4) & 5.58 & 1.20 & 5.22 & 1.25 & 4.61 & 1.95 & ns & $c>t$ & ns \\
\hline & & & SPDT & TALS & 5.59 & 0.59 & 5.26 & 0.68 & 4.98 & 0.86 & $c>s$ & $c>t$ & ns \\
\hline
\end{tabular}




\section{SIMILAR PHONEMES (SMLP)}

\begin{tabular}{|c|c|c|c|c|c|c|c|c|c|c|c|c|c|c|}
\hline \multirow{2}{*}{$\begin{array}{l}\text { PR } \\
\# \\
49^{\circ}\end{array}$} & \multirow{2}{*}{$\begin{array}{l}\begin{array}{l}\text { Simp } \\
\text { Char }\end{array} \\
\text { 坟 }\end{array}$} & \multirow{2}{*}{$\begin{array}{l}\text { Com } \\
\text { Char } \\
\text { 墳 }\end{array}$} & \multirow{2}{*}{$\begin{array}{l}\text { Hanyu } \\
\text { Pinyin } \\
\text { fen(2) }\end{array}$} & \multicolumn{2}{|c|}{$\begin{array}{l}\text { Phonetic Radical } \\
\& \text { Hanyu Pinyin }\end{array}$} & \multicolumn{2}{|c|}{$\begin{array}{c}\text { China } \\
\text { Mean/SD }\end{array}$} & \multicolumn{2}{|c|}{$\begin{array}{l}\text { Singapore } \\
\text { Mean/SD }\end{array}$} & \multicolumn{2}{|c|}{$\begin{array}{l}\text { Taiwan } \\
\text { Mean/SD }\end{array}$} & \multirow{2}{*}{$\begin{array}{l}\mathrm{C} / \mathrm{S} \\
.05 \\
c>s\end{array}$} & \multirow{2}{*}{$\begin{array}{l}\mathrm{C} / \mathrm{T} \\
.05 \\
\mathrm{~ns}\end{array}$} & \multirow{2}{*}{$\begin{array}{l}\mathrm{S} / \mathrm{T} \\
.05 \\
\mathrm{DS}\end{array}$} \\
\hline & & & & 文 & wen(2) & 4.16 & 2.17 & 3.07 & 2.06 & 4.16 & 1.94 & & & \\
\hline 50 & 袖 & & $\operatorname{xiu}(4)$ & 由 & you(2) & 3.23 & 2.03 & 2.33 & 1.53 & 2.55 & 1.95 & $\mathrm{c}>\mathrm{s}$ & ns & ns \\
\hline 51 & 悄 & & qiao(1) & 肖 & $x \operatorname{iao}(1)$ & 4.33 & 1.80 & 4.26 & 1.58 & 3.43 & 2.09 & ns & $c>t$ & $s>t$ \\
\hline $52^{b}$ & $\sqrt{\mathrm{J}}$ & 魔 & ting(1) & J & $\operatorname{ding}(1)$ & 4.40 & 1.90 & 4.94 & 1.35 & 6.51 & 1.30 & ns & $\triangleright c$ & $1>s$ \\
\hline 53 & 板 & & $\operatorname{ban}(3)$ & 反 & $f a n(3)$ & 3.48 & 1.90 & 3.82 & 1.80 & 3.57 & 2.19 & ns & ns & ns \\
\hline 54 & 愧 & & kui(4) & 鬼 & gui(3) & 4.30 & 1.88 & 4.74 & 1.28 & 3.98 & 1.91 & ns & ns & $s>t$ \\
\hline 55 & 持 & & $\operatorname{chi}(2)$ & 寺 & $\operatorname{si}(4)$ & 2.28 & 1.82 & 3.60 & 1.59 & 3.66 & 2.04 & $s>c$ & $\triangleright c$ & ns \\
\hline 56 & 迨 & & dai(4) & 台 & $\operatorname{tai}(2)$ & 3.52 & 2.32 & 4.25 & 2.12 & 3.68 & 2.28 & ns & ns & ns \\
\hline 57 & 淙 & & cong(2) & 宗 & zong(1) & 5.81 & 1.56 & 5.97 & 1.50 & 5.82 & 1.50 & ns & ns & ns \\
\hline 58 & 汗 & & han(4) & 干 & $\operatorname{gan}(1)$ & 2.95 & 2.03 & 2.84 & 1.67 & 2.24 & 1.85 & ns & ns & ns \\
\hline 59 & 浩 & & hao(4) & 告 & gao(4) & 3.61 & 1.98 & 3.45 & 1.71 & 3.62 & 2.00 & ns & ns & ns \\
\hline $60^{b}$ & 灿 & 燦 & $\operatorname{can}(4)$ & 山 & $\operatorname{shan}(1)$ & 1.94 & 1.42 & 2.96 & 1.83 & 4.10 & 2.63 & $s>c$ & $D c$ & $\gg \mathrm{s}$ \\
\hline 61 & 杞 & & $q i(3)$ & $\vec{~}$ & $\mathrm{ji}(3)$ & 4.00 & 2.09 & 4.99 & 1.88 & 3.54 & 2.41 & $\mathrm{~s}>\mathrm{c}$ & ns & $s>t$ \\
\hline $62^{\mathrm{a}}$ & 踌 & 蹼 & chou(2) & 寿 & shou(4) & 2.91 & 2.20 & 2.89 & 1.85 & 3.02 & 2.09 & ns & ns & ns \\
\hline 63 & 洪 & & hong(2) & 䒔 & gong(4) & 3.18 & 1.93 & 3.55 & 1.74 & 3.02 & 2.17 & ns & ns & ns \\
\hline $64^{\mathrm{c}}$ & 终 & 終 & zhong(1) & 冬 & dong (1) & 2.85 & 1.86 & 2.81 & 1.70 & 3.12 & 2.14 & ns & ns & ns \\
\hline 65 & 跑 & & pao(3) & 包 & bao(1) & 4.07 & 1.91 & 4.10 & 1.45 & 4.27 & 1.89 & ns & ns & ns \\
\hline 66 & 批 & & pi(1) & 比 & bi(3) & 4.40 & 1.79 & 4.90 & 1.24 & 4.84 & 1.76 & ns & ns & ns \\
\hline $67^{\mathrm{a}}$ & 宠 & 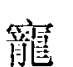 & chong(3) & 龙 & long(2) & 2.78 & 2.12 & 2.11 & 1.51 & 2.69 & 2.20 & ns & ns & ns \\
\hline 68 & 肚 & & $\mathrm{du}(4)$ & \pm & tu(3) & 2.67 & 1.73 & 3.70 & 1.74 & 4.00 & 2.11 & $\mathrm{~s}>\mathrm{c}$ & $1>c$ & ns \\
\hline 69 & 枯 & & $\mathrm{ku}(1)$ & 古 & $\mathrm{gu}(3)$ & 4.55 & 1.81 & 4.76 & 1.26 & 4.73 & 2.01 & ns & ns & $\mathrm{ns}$ \\
\hline 70 & 精 & & jing( & 青 & qing & 4.28 & 1.94 & 4.63 & 1.50 & 4.63 & 192 & ns & ns & ns \\
\hline 71 & 拼 & & $\operatorname{pin}(1)$ & 并 & bing(4) & 3.55 & 2.06 & 4.71 & 1.38 & 4.57 & 2.17 & $\mathrm{~s}>\mathrm{c}$ & $1>c$ & ns \\
\hline 72 & 诱 & & you(4) & 秀 & $\operatorname{xiu}(4)$ & 3.70 & 2.02 & 3.19 & 2.00 & 4.40 & 2.38 & ns & ns & $\triangleright s$ \\
\hline & & & S. & & & 3.62 & 1.01 & 3.83 & 0.80 & 3.92 & 1.12 & ns & ns & ns \\
\hline
\end{tabular}


APPENDIX B (Continued)

\section{DIFFERENT PHONEMES (DFTP)}

\begin{tabular}{|c|c|c|c|c|c|c|c|c|c|c|c|c|c|}
\hline \multirow{2}{*}{ 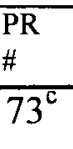 } & \multirow{2}{*}{$\begin{array}{l}\text { Simp } \\
\text { Char } \\
\text { 讨 }\end{array}$} & \multirow{2}{*}{$\begin{array}{l}\text { Com } \\
\text { Char } \\
\text { 討 }\end{array}$} & \multirow{2}{*}{$\begin{array}{l}\text { Hanyu } \\
\text { Pinyin } \\
\text { tao(3) }\end{array}$} & $\begin{array}{l}\text { Phonetic Radical } \\
\text { \& Hanyu Pinyin }\end{array}$ & \multicolumn{2}{|c|}{$\begin{array}{c}\text { China } \\
\text { Mean/SD }\end{array}$} & \multicolumn{2}{|c|}{$\begin{array}{l}\text { Singapore } \\
\text { Mean/SD }\end{array}$} & \multicolumn{2}{|c|}{$\begin{array}{c}\text { Taiwan } \\
\text { Mean/SD }\end{array}$} & \multirow{2}{*}{$\begin{array}{l}\mathrm{C} / \mathrm{S} \\
.05 \\
\mathrm{~ns}\end{array}$} & \multirow{2}{*}{$\begin{array}{l}\mathrm{C} / \mathrm{T} \\
.05 \\
\mathrm{~ns}\end{array}$} & \multirow{2}{*}{$\begin{array}{l}. \mathrm{S} / \mathrm{T} \\
.05 \\
\mathrm{~ns}\end{array}$} \\
\hline & & & & 才 $\operatorname{cun}(4)$ & 1.46 & 1.29 & 1.34 & 0.84 & 1.41 & 1.24 & & & \\
\hline 74 & 奸 & & jian(1) & 干 $\operatorname{gan}(1)$ & 1.76 & 1.71 & 1.44 & 1.03 & 1.59 & 1.37 & ns & ns & ns \\
\hline 75 & 魂 & & $\operatorname{hun}(2)$ & 鬼 gui(3) & 2.06 & 1.87 & 1.47 & 1.13 & 1.35 & 0.98 & $c>s$ & $c>t$ & ns \\
\hline 76 & 社 & & she(4) & $+\quad \operatorname{tu}(3)$ & 1.25 & 0.68 & 1.27 & 0.73 & 1.47 & 1.29 & ns & ns & ns \\
\hline 77 & 拙 & & zhuo(1) & 出 chu(1) & 2.21 & 1.97 & 2.36 & 1.64 & 1.75 & 1.51 & ns & ns & ns \\
\hline 78 & 仙 & & $x \operatorname{ian}(1)$ & 山 $\operatorname{shan(1)}$ & 2.57 & 1.69 & 1.88 & 1.46 & 2.29 & 1.84 & $c>s$ & ns & ns \\
\hline 79 & 妃 & & fei(1) & 己 $\mathrm{ji}(3)$ & 2.07 & 1.72 & 1.55 & 1.33 & 1.41 & 1.30 & $\mathrm{~ns}$ & $c>t$ & ns \\
\hline $80^{\mathrm{a}}$ & 庞 & 㡴 & $\operatorname{pang}(2)$ & 龙 long(2) & 2.37 & 2.09 & 1.55 & 1.32 & 2.57 & 2.29 & $>s$ & ns & $t>s$ \\
\hline 81 & 脾 & & $\mathrm{pi}(2)$ & 卑 bei(1) & 4.67 & 2.08 & 3.34 & 2.02 & 4.10 & 2.31 & $>s$ & ns & ns \\
\hline 82 & 猜 & & cai(1) & 青 qing(1) & 1.34 & 0.91 & 1.53 & 1.11 & 1.44 & 1.13 & ns & $\mathrm{ns}$ & ns \\
\hline 83 & 的 & & gui(1) & 反 $\operatorname{fan}(3)$ & 3.66 & 2.12 & 2.75 & 1.99 & 4.04 & 2.43 & ns & ns & $p s$ \\
\hline $84^{\mathrm{a}}$ & 扰 & 揹 & $\operatorname{rao}(3)$ & 尤 you(2) & 2.64 & 2.25 & 2.34 & 2.02 & 2.10 & 1.96 & $\mathrm{~ns}$ & ns & ns \\
\hline $85^{\mathrm{a}}$ & 脸 & 腧 & kuai(4) & 会 hui(4) & 4.57 & 2.49 & 2.67 & 2.21 & 4.36 & 2.41 & $c>s$ & ns & t>s \\
\hline 86 & 埋 & & $\operatorname{mai}(2)$ & 里 $\mathrm{li}(3)$ & 1.61 & 1.69 & 1.53 & 1.50 & 1.76 & 1.69 & ns & $\mathrm{ns}$ & ns \\
\hline 87 & 姓 & & xing(4) & 生 sheng(1) & 2.21 & 1.68 & 1.49 & 0.97 & 1.75 & 1.53 & $c>s$ & ns & ns \\
\hline 88 & 始 & & $\operatorname{shi}(3)$ & 台 $\operatorname{tai}(2)$ & 1.36 & 1.23 & 1.22 & 0.77 & 1.29 & 1.04 & ns & ns & ns \\
\hline 89 & 疼 & & teng(2) & 冬 dong(1) & 2.82 & 1.97 & 2.45 & 1.46 & 2.49 & 1.83 & ns & $\mathrm{ns}$ & ns \\
\hline 90 & 打 & & $\mathrm{da}(3)$ & $\Gamma \operatorname{ding}(1)$ & 1.49 & 1.45 & 1.18 & 0.54 & 1.31 & 0.95 & $\mathrm{~ns}$ & ns & ns \\
\hline $91^{\mathrm{a}}$ & 涛 & 漬 & $\operatorname{tao}(1)$ & 寿 shou(4) & 2.09 & 1.93 & 1.64 & 1.38 & 2.16 & 2.05 & ns & ns & ns \\
\hline 92 & 扯 & & che(3) & It $\operatorname{zhi}(3)$ & 2.75 & 2.16 & 3.74 & 2.07 & 2.75 & 2.43 & $s>c$ & $\mathrm{~ns}$ & $s>t$ \\
\hline 93 & 抽 & & chou(1) & 由 $y o u(2)$ & 2.45 & 2.01 & 1.38 & 1.04 & 2.22 & 1.86 & $c>s$ & ns & $t>s$ \\
\hline 94 & 酷 & & $\mathrm{ku}(4)$ & 告 $\operatorname{gao}(4)$ & 1.87 & 1.41 & 1.89 & 1.23 & 2.49 & 1.98 & ns & ns & $\mathrm{ns}$ \\
\hline 95 & 特 & & te(4) & 导 $\operatorname{si}(4)$ & 1.30 & 0.85 & 1.38 & 0.76 & 1.65 & 1.37 & ns & ns & ns \\
\hline 96 & 咬 & & yao(3) & 交 jiao(1) & 3.61 & 1.92 & 2.44 & 1.60 & 2.88 & 2.10 & $c>s$ & ns & ns \\
\hline & & & DFTP & OTALS & 2.33 & 0.74 & 1.90 & 0.62 & 2.19 & 0.82 & $c>s$ & ns & ns \\
\hline & & & GRAN & D TOTALS & 4.54 & 0.52 & 4.34 & 0.49 & 4.39 & 0.69 & & $\mathrm{~ns}$ & ns \\
\hline
\end{tabular}

a phonetic radical simplified; ${ }^{b}$ phonetic radical changed; ${ }^{c}$ semantic radical simplified

(Manuscript received September 9,1996;

revision accepted for publication October 8,1997.) 